\title{
The dual topoisomerase inhibitor A35 preferentially and specially targets topoisomerase $2 \alpha$ by enhancing pre-strand and post-strand cleavage and inhibiting DNA religation
}

\author{
Wuli Zhao ${ }^{1, *}$, Guohua Jiang ${ }^{2, *}$, Chongwen Bi ${ }^{1}$, Yangbiao Li ${ }^{1}$, Jingbo Liu ${ }^{3}$, Cheng Ye ${ }^{1}$, \\ Hongwei He ${ }^{1}$, Liang $\mathrm{Li}^{1}$, Danqing Song ${ }^{1, *}$, Rongguang Shao ${ }^{1, *}$ \\ ${ }^{1}$ Key Laboratory of Antibiotic Bioengineering, Ministry of Health, Laboratory of Oncology, Institute of Medicinal Biotechnology, \\ Peking Union Medical College and Chinese Academy of Medical Sciences, Beijing, China \\ ${ }^{2}$ Analysis and Testing Center, Beijing Normal University, Beijing, China \\ ${ }^{3}$ China Meitan General Hospital, Beijing, China \\ * These authors have contributed equally to this work \\ Correspondence to: \\ Rongguang Shao, e-mail: rgshao@163.com \\ Keywords: dual topoisomerase inhibitor, topoisomerase $2 \alpha$, cardiotoxicity, DNA religation, enhancing strand cleavage \\ Received: May 24, $2015 \quad$ Accepted: September 25, $2015 \quad$ Published: October 07, 2015
}

\section{ABSTRACT}

DNA topoisomerases play a key role in tumor proliferation. Chemotherapeutics targeting topoisomerases have been widely used in clinical oncology, but resistance and side effects, particularly cardiotoxicity, usually limit their application. Clinical data show that a decrease in topoisomerase (top) levels is the primary factor responsible for resistance, but in cells there is compensatory effect between the levels of top 1 and top $2 \alpha$. Here, we validated cyclizing-berberine A35, which is a dual top inhibitor and preferentially targets top $2 \alpha$. The impact on the top $2 \alpha$ catalytic cycle indicated that A35 could intercalate into DNA but did not interfere with DNA-top binding and top $2 \alpha$ ATPase activity. A35 could facilitate DNA-top $2 \alpha$ cleavage complex formation by enhancing pre-strand and post-strand cleavage and inhibiting religation, suggesting this compound can be a topoisomerase poison and had a district mechanism from other topoisomerase inhibitors. TARDIS and comet assays showed that A35 could induce cell DNA breakage and DNA-top complexes but had no effect on the cardiac toxicity inducer top2 $\beta$. Silencing top 1 augmented DNA break and silencing top $2 \alpha$ decreased DNA break. Further validation in H9c2 cardiac cells showed A35 did not disturb cell proliferation and mitochondrial membrane potency. Additionally, an assay with nude mice further demonstrated A35 did not damage the heart. Our work identifies A35 as a novel skeleton compound dually inhibits topoisomerases, and predominantly and specially targets top $2 \alpha$ by interfering with all cleavage steps and its no cardiac toxicity was verified by cardiac cells and mice heart. A35 could be a novel and effective targeting topoisomerase agent.

\section{INTRODUCTION}

DNA topoisomerases are essential enzymes for cells to modulate DNA topology by regulating the over- or under-winding of DNA strands during cellular processes such as DNA transcription, replication, or recombination [1]. Top1 is a nuclear enzyme that catalyzes the relaxation of superhelical DNA by generating a transient single strand nick. Top2 mediates the ATPdependent induction of coordinated nicks in both strands of the DNA duplex, followed by the crossing of another double strand of DNA through the transiently broken duplex. Two top2 isozymes are expressed in humans: top $2 \alpha$ and top $2 \beta$. Top $2 \alpha$ is most abundantly expressed in rapidly growing tissues, and its expression is cell cycleregulated, peaking during $\mathrm{G} 2 / \mathrm{M}$. In contrast, top $2 \beta$ is ubiquitously expressed in terminally differentiated cells including cardiomyocytes and its expression levels do not exhibit any significant changes during the cell cycle [2-5]. 
Given that they are highly expressed in aggressive cancer cells and are essential to cancer cell survival, top1 and top $2 \alpha$ are potential drug targets for treating human malignancies. Compared with top 1 , top $2 \alpha$ is more essential for cell viability because only top $2 \alpha$ can drive the separation of two DNA duplexes after replication and its deletion is lethal for cell survival [6-8]. Chemotherapeutics targeting top 1 and in particular top $2 \alpha$ have been of great utility in clinical oncology. Although these drugs are highly effective, tumors frequently recur and even become resistant, and the occurrence of side effects, particularly cardiotoxicity and secondary malignancies, tremendously limit their application. Some studies have shown that decreased topoisomerase levels in relapsed tumors contribute to the tumor resistance $[9,10]$; additionally, researchers also found that there is a compensatory effect between top 1 and top $2 \alpha$ : when the expression of one type of topisomerase is decreased, the other will be increased [9, 11-13]. Some evidence regarding the adverse effects, particularly anthracyclineinduced cardiotoxicity mediated by targeting top2 indicated that non-specific targeting of top $2 \beta$ is the initial molecular mechanism underlying this phenomenon [14]. Thus, to overcome the above-mentioned drug resistance and cardiotoxicity, combinatorial targeting of top 1 and top $2 \alpha$ is essential, but recent clinical data have shown that the combination of top 1 and top $2 \alpha$ poisons might lead to severe life-threatening neutropenia and anemia resulting from the toxicity overlay of the two agents [13]. Thus, it is extremely important to identify a compound that simultaneously targets top 1 and top $2 \alpha$. Although some researchers have investigated compounds that could target top 1 and top2, they did not precisely elucidate whether the top 2 target is top $2 \alpha$ or top $2 \beta$ [15-18]. Recently, one study in the literature reported an agent that could inhibit top 1 and top $2 \alpha$, but it did not further clarify its effects on top $2 \beta$ [19]. Additionally, the predicted lack of cardiac toxicity of reported inhibitors specifically targeting top $2 \alpha$ was obtained only based on a cell-free assay (DNA directly incubated with synthetic topoisomerase in buffer); further validation in cardiac cells and drugs effects on animal cardiac muscle were not reported [20-23].

Berberine (BBR, Figure 1A, left), an isoquinoline natural product extracted from Coptis chinensis, has been extensively used as an anti-inflammatory [24], cholesterol-lowering [25] and antineoplastic [26] research agent. However, its anticancer activity is weak [26, 27]. Cyclizing-berberine is a novel skeleton compound (berberine of 1, 13-cyclication) that is occasionally obtained during the structural transformation of berberine in the search for a highly effective cholesterol-lowering agent. A screen found that this class of compound could inhibit cell proliferation; this detection evoked our interest to determine whether this novel structural class compound induced anticancer activity.
Via successive structural transformation (A series of new cyclizing-berberine derivatives were synthesized through variations at the 9-position) and repetitive cytotoxicity assays, cyclizing-berberine A35 (replacement of 9-methoxyl with an ester moiety) (Figure 1A, right) emerged and contained a greater number of aromatic rings that facilitate intercalation into DNA or topoisomerase, and also displayed excellent anticancer activity that was clearly better than its parent berberine (data not shown). A toxicity assay further confirmed its lower toxicity $(300 \mathrm{mg} / \mathrm{kg}$ administration by intraperitoneal injection; the mouse survival rate was $100 \%$ ).

In the present study, we evaluated the novel skeleton compound A35 in a cell-free assay, a cell assay and in further animal experiments and demonstrated that A35 could target top 1 and particularly top $2 \alpha$ by increasing pre-strand and post-strand cleavage and inhibiting the religation. Additionally, we also illustrated that A 35 could specifically target top $2 \alpha$ and not top $2 \beta$; meanwhile, we confirmed that A35 did not induce cardiac cell injury in rat cardiomyocyte cells and nude mouse hearts.

\section{RESULTS}

\section{A35 is a dual inhibitor of top2 $\alpha$ and top1}

Given that A35 possesses a greater number of aromatic rings and its structure is similar to known topoisomerase 2 inhibitors [22, 23], we first examined the effects of A35 on top $2 \alpha$ activity by top $2 \alpha$-mediated relaxation assay. As shown in Figure 1B, A35 significantly inhibited top $2 \alpha$ relaxation activity in a concentrationdependent manner. The relaxed DNA was quantified by software Image J and IC50 (a concentration resulting in $50 \%$ relaxed DNA reduction) was calculated as $0.56 \mu \mathrm{M}$ by SigmaPlot. At the same concentration $(10 \mu \mathrm{M})$, inhibitory activity of A35 on top top $2 \alpha$ was much higher than that of etoposide (VP16), indicating that A35 was a powerful top $2 \alpha$ inhibitor. Then, we utilized top1-mediated cleavage assay with linear DNA as substrate to evaluate the effect of A35 on top1, and results showed that A35 could induce linear DNA breakage in dose-dependent manner (Figure 1C), although the DNA breakage effect was weak and far less than the positive control TPT (topotecan), a water-soluble derivative of alkaloid camptoth ecin (CPT) and could stabilize top1 cleavage complexes [28, 29], indicating A35 could inhibit top1 activity. Similarly top1-mediated relaxation assay showed that the IC50 of A35 on top 1 was $22.1 \mu \mathrm{M}$ that was far higher than the IC50 of A35 on top $2 \alpha$ (data not shown). These results showed that A35 could dually inhibit top $2 \alpha$ and top 1 , although the effect on top $2 \alpha$ was be superior to the effect on top1. 


\section{A35 can intercalate DNA but does not interfere with top $2 \alpha$-DNA binding and top2 $\alpha$ ATPase activity}

Given that top $2 \alpha$ is indispensable for cell division and was strongly inhibited by A35, in the following experiment we focused on investigating the effects of A35 on top $2 \alpha$. There are several steps in the top $2 \alpha$ catalytic cycle. As a consequence, multiple independent approaches are required to determine the mechanisms underlying the drug-mediated inhibition of top $2 \alpha$. For A35, its intercalation into DNA is attributed to its polar structure, and this intercalation might lead to the topoisomerase DNA binding site being occupied or distortion of the DNA backbone; this can then interfere with top2-DNA binding. The ability of A35 to intercalate DNA was assessed using a top1 unwinding assay as described [20], pBR322DNA was firstly relaxed by top 1 and mAMSA (amsacrine) (a known DNA intercalator) as a positive control [30] or A35 was added, then we observed the negative supercoiling formed after the addition of mAMSA or A35 (Figure 2A). The relaxed DNA was quantified, and the dose-response curve and IC50 (a concentration of 50\% relaxed DNA reduction) showed almost identical DNA intercalation activity between A35 and mAMSA, indicating that A35 was a DNA intercalator.

Given that A35 could intercalate into DNA, we utilized an EMSA assay [31, 32] to measure whether

A<smiles>COc1ccc2cc3[n+](cc2c1OC)CCc1cc2c(cc1-3)OCO2</smiles><smiles></smiles>

Berberine

A35

B
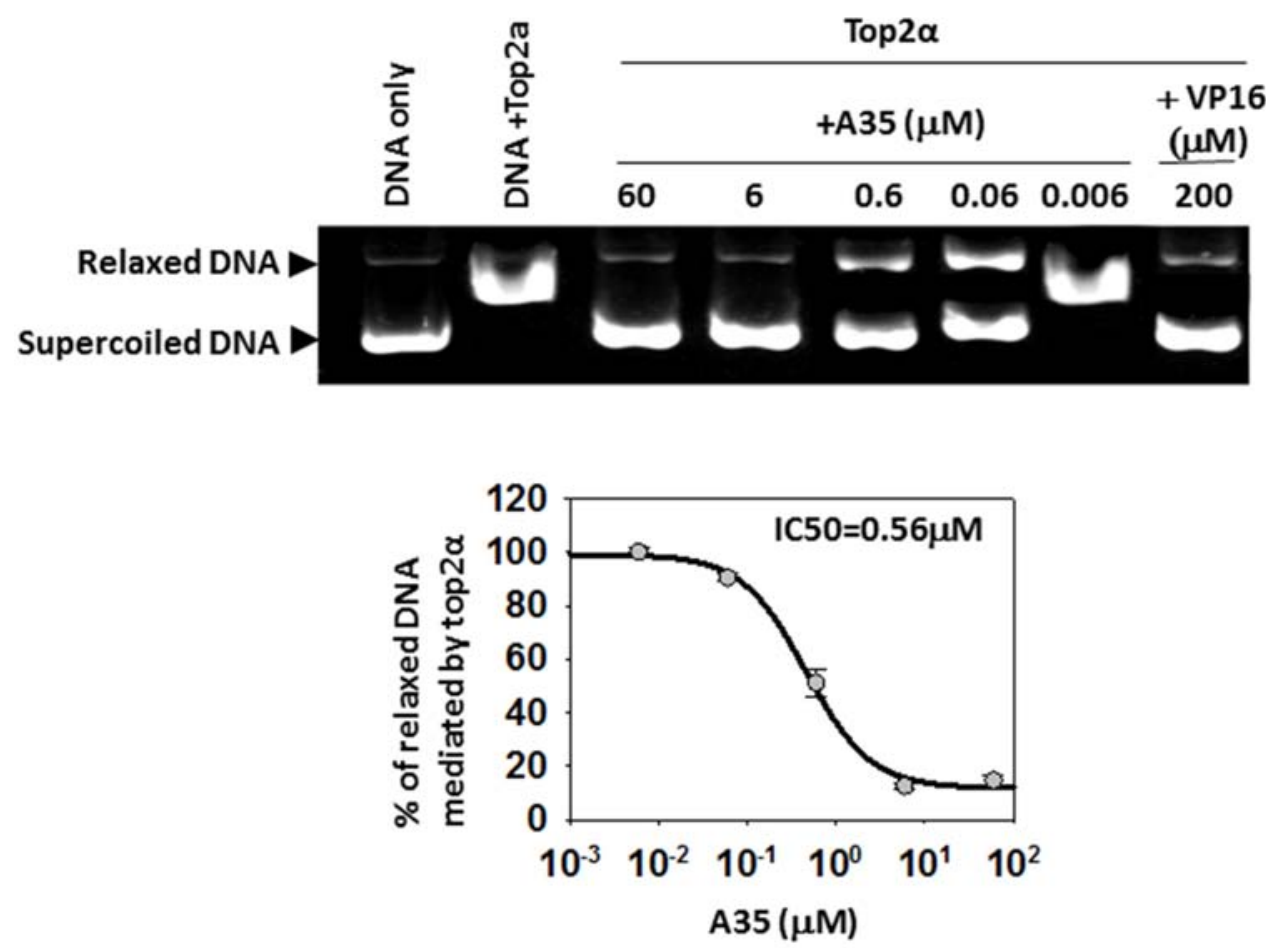

Figure 1: A35 is a dual inhibitor of top2 $\alpha$ and top1. A. The structure of Berberine and A35.

(Continued) 

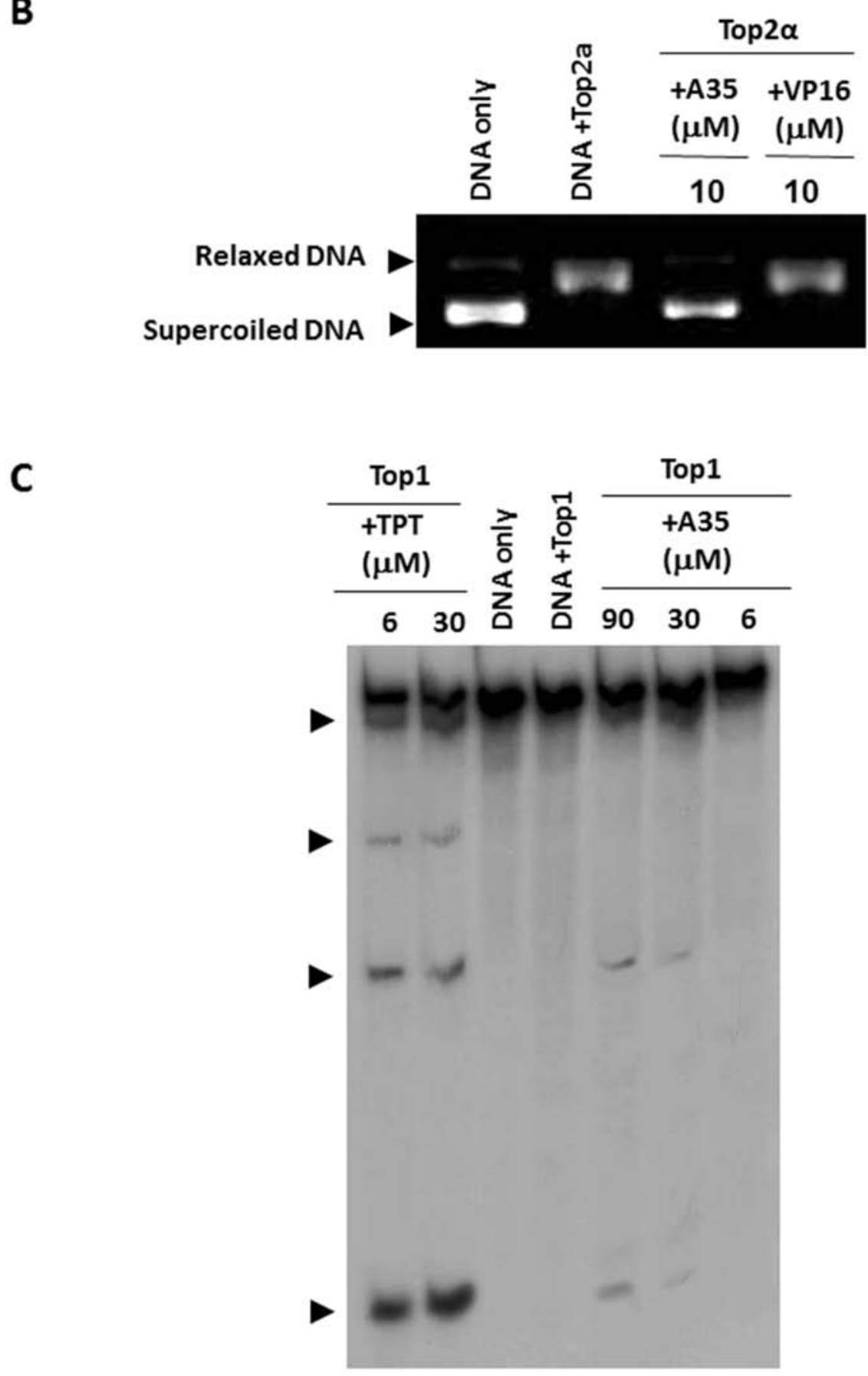

Figure 1 (Continued): B. $0.5 \mu \mathrm{g}$ supercoiled plasmid pBR322DNA was incubated with top2 $\alpha$ and various concentrations of A35 or the indicated agents for $30 \mathrm{~min}$. The reaction was stopped and the reaction products were separated in $1 \%$ agarose. RLX, relaxed DNA; SC, supercoiled DNA. The relaxed DNA was scanned by Image J and the IC50 was defined as the concentration of A35 resulting in a 50\% reduction of relaxed DNA. Data represent the mean \pm S.E.M. of three independent experiments. C. 3'-end-labeled 117-bp oligonucleotide was reacted with top1 (60U) in the presence or absence of indicated concentrations of compound. Arrowheads indicate the migration positions of DNA fragments cleaved by top 1 in the presence of compounds.

A35 interfered with top2 $\alpha$-DNA binding (Figure 2B) as described. A DNA probe containing a robust top2 $\alpha$-binding site was synthesized and incubated with nuclear extracts; after electrophoresis, we observed the DNA-top $2 \alpha$ binding complex at the position of the top $2 \alpha$ protein in the gel, and further verification that the complex contained the top $2 \alpha$ protein was obtained via supershift assay with the antitop $2 \alpha$ antibody. Additionally, we determined that A35 did 
not disturb DNA-top $2 \alpha$ binding at various concentrations; interestingly we found that at $6 \mu \mathrm{M}$ A35 seemingly promoted the binding of DNA and top $2 \alpha$ slightly, and at the highest concentration of $120 \mu \mathrm{M}$ the binding activity decreased compared with $6 \mu \mathrm{M}$.

The effect of A35 on top $2 \alpha$ ATP enzyme activity was examined by thin layer chromatography with $[\gamma-32 \mathrm{P}]-\mathrm{ATP}$ and results showed that novobiocin (a known top2 $\alpha$ ATP enzyme inhibitor) [33] significantly suppressed top $2 \alpha-$ mediated ATP hydrolysis, demonstrating that the assay was credible. But in A35-treated groups, we did not observe significant changes of ATP hydrolysis mediated by top $2 \alpha$, indicating that A35 did not inhibit top $2 \alpha$ ATP enzyme activity (Figure 2C).
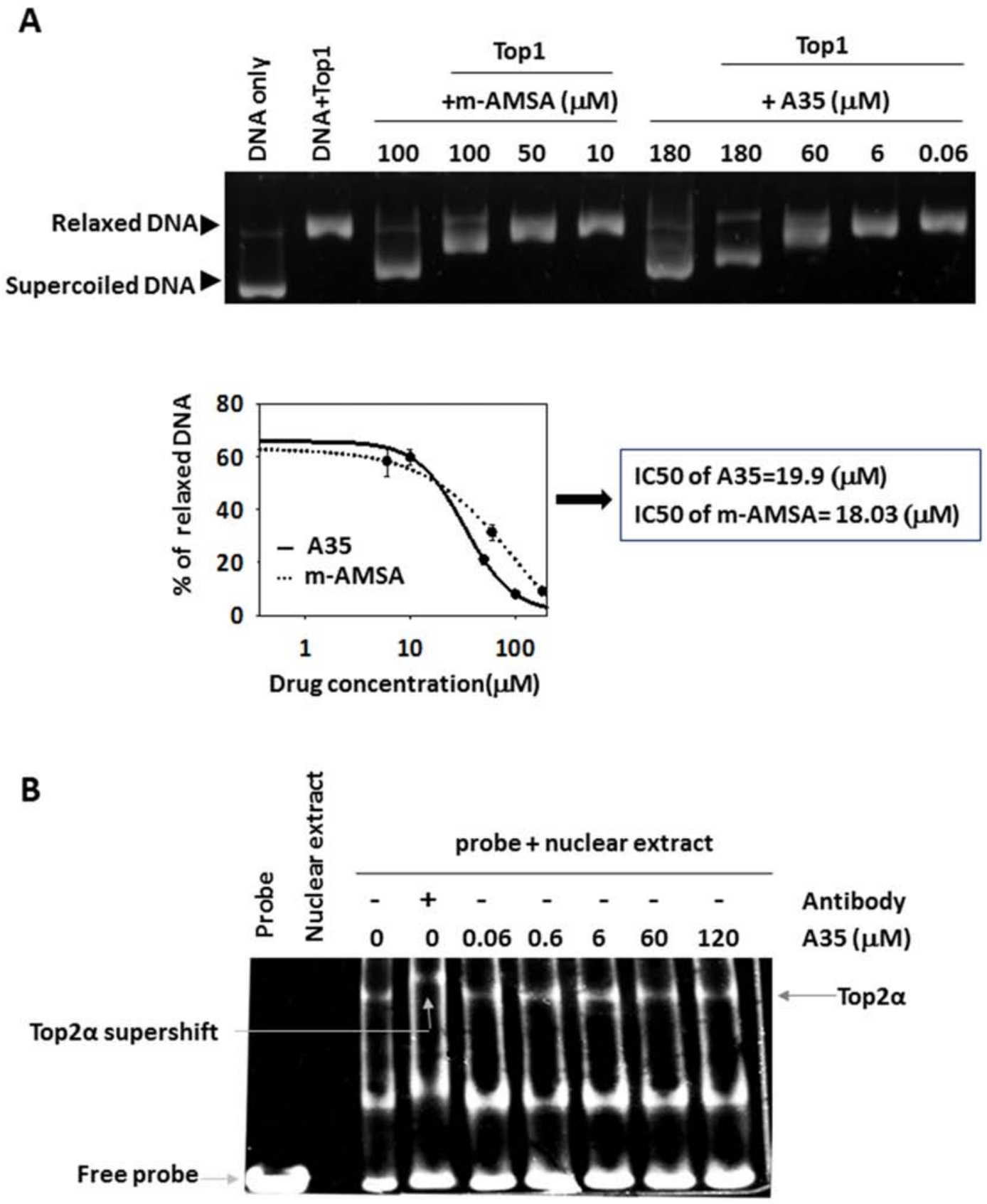

Figure 2: A35 can intercalate DNA but does not interfere with top2 $\alpha$-DNA binding and top2 $\alpha$ ATPase activity. A. Plasmid pBR322 DNA was firstly relaxed by top1 prior to the addition of the indicated concentration agents and incubated for a further 30 min at $37^{\circ} \mathrm{C}$. Reaction products were resolved on an agarose gel prior to visualization with ethidium bromide. The relaxed DNA was scanned and the dose response curves and IC50 were plotted and depicted. The IC50 represents the concentration required to facilitate 50\% relaxed DNA to form supercoiled DNA.

(Continued) 


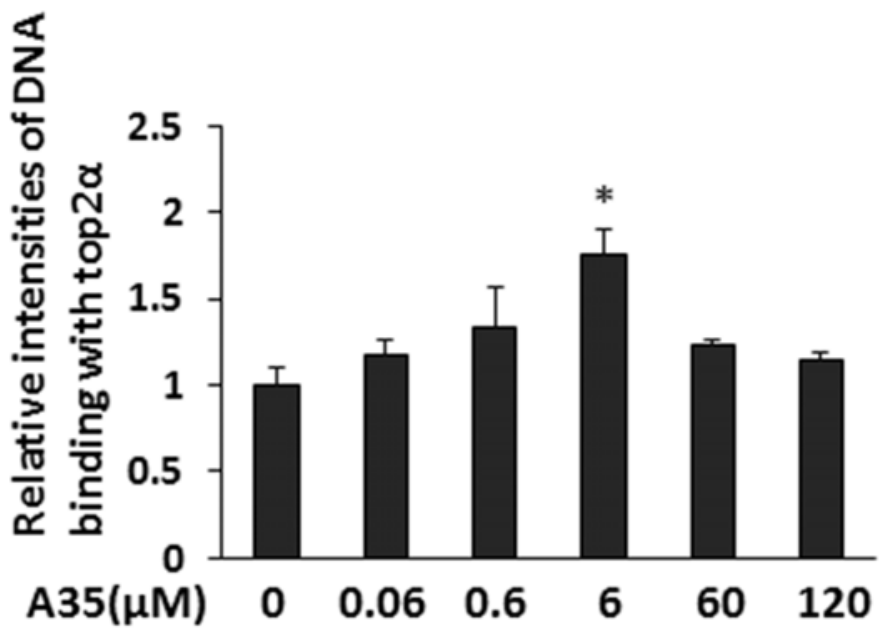

C

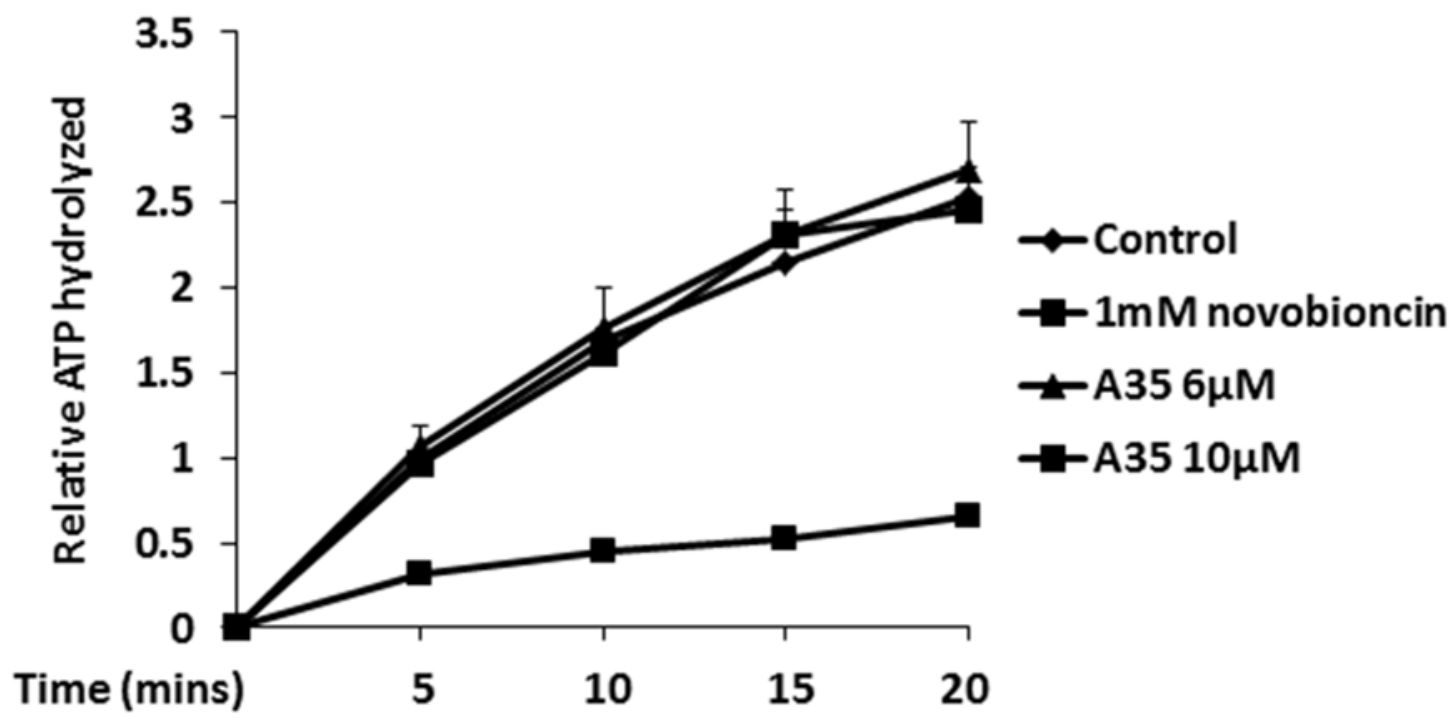

Figure 2 (Continued): B. K562 nuclear extracts were incubated with $1 \mathrm{~nm}$ double-stranded oligonucleotide containing a strong top $2 \alpha$ binding site in the presence of increasing concentrations of A35. After supershifting, an antibody was first incubated with nuclear extracts, and then the DNA probe and compound were added. Reaction products were resolved by non-denaturing polyacrylamide gel electrophoresis, the intensities of band were scanned and the relative ratio to nuclear extract + probe was plotted. C. The effects of A35 on top $2 \alpha$ hydrolysis activity were determined by thin layer chromatography with $[\gamma 32 \mathrm{P}]-\mathrm{ATP}$ in the presence of indicated compounds. Samples from various time points were quantified by scintillation counting and plotted relative ratio to the 5 min scintillation counting of control.

\section{A35 facilitates top2 $\alpha$-DNA cleavage complex formation by simultaneously enhancing pre-strand and post-strand cleavage and inhibiting DNA religation}

Then we evaluated the effect of A35 on the DNA cleavage. A cleavage assay in the presence of $8 \mathrm{U}$ top $2 \alpha$,
$0.2 \mu \mathrm{g}$ pBR322 and increasing concentrations of A35 was performed, and the results showed that cleaved linear DNA was formed and the cleaved band presented in a dose-dependent manner (Figure 3A). Together, these results indicated that A35 stabilized the DNA-enzyme complex and thus this compound belongs to the poison of topoisomerase inhibitors. 
Usually pre-strand cleavage and post-strand cleavage participated in the top $2 \alpha$-mediated DNA cleavage process [20]. Interference with any step would induce the occurrence of DNA cleavage and linear DNA formation. As ATP is required for strand passage, in the absence of ATP top2 binds DNA and establishes prestrand cleavagereligation equilibrium prior to strand passage. As seen in
Figure 3B, a significant increase in the amount of cleaved linear DNA was observed by addition of A35 (120 $\mu \mathrm{M}$ and $30 \mu \mathrm{M})$ and the cleaved band presented in a dose-dependent manner, indicating that A35 enhanced pre-strand cleavage reaction. Just in accordance with previous description [20], meso-4,4'-(3,2-butanediyl)-bis(2,6-piperazinedione) (ICRF-193) inhibited enzyme activity at the post-cleavage

A
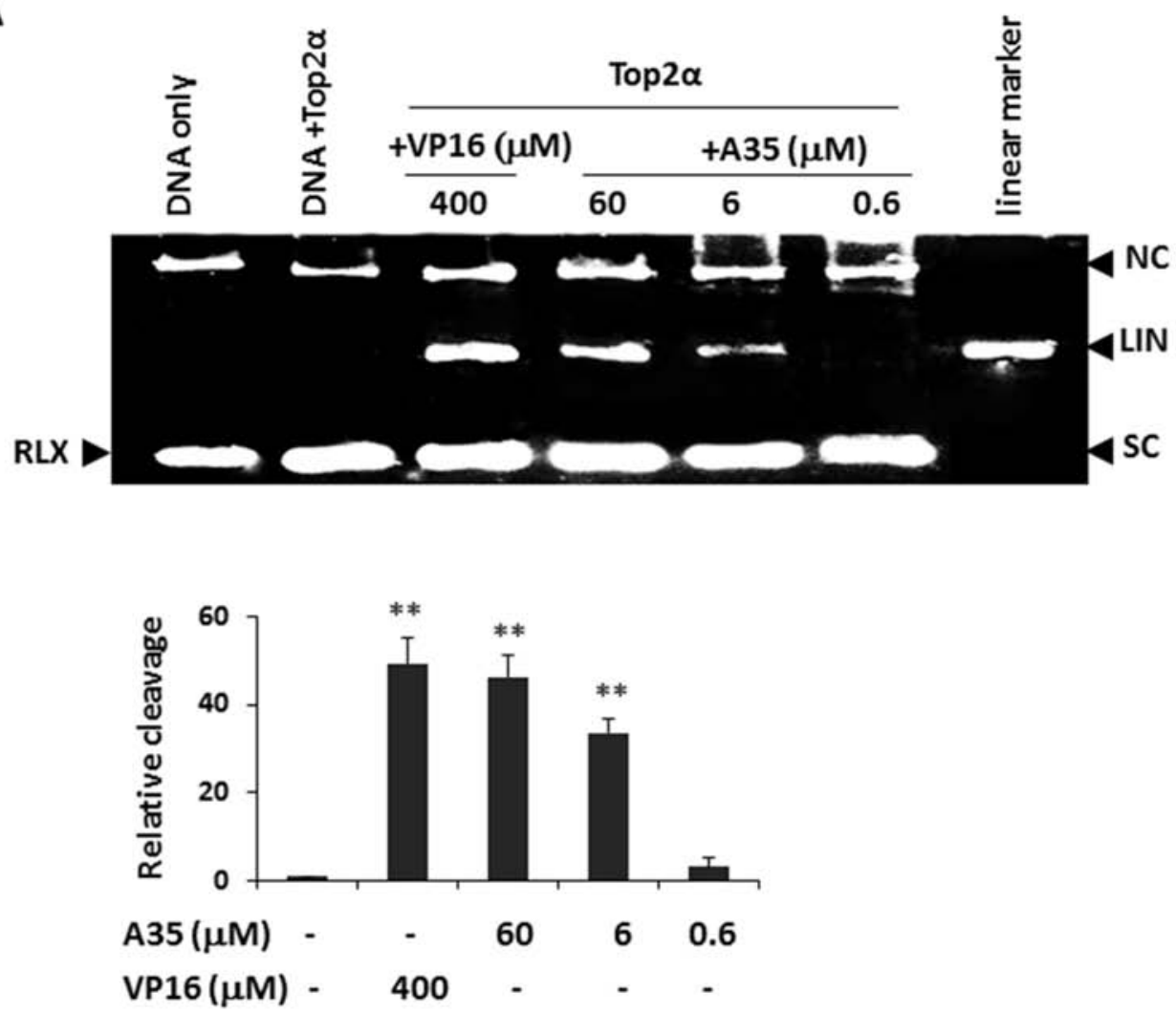

B

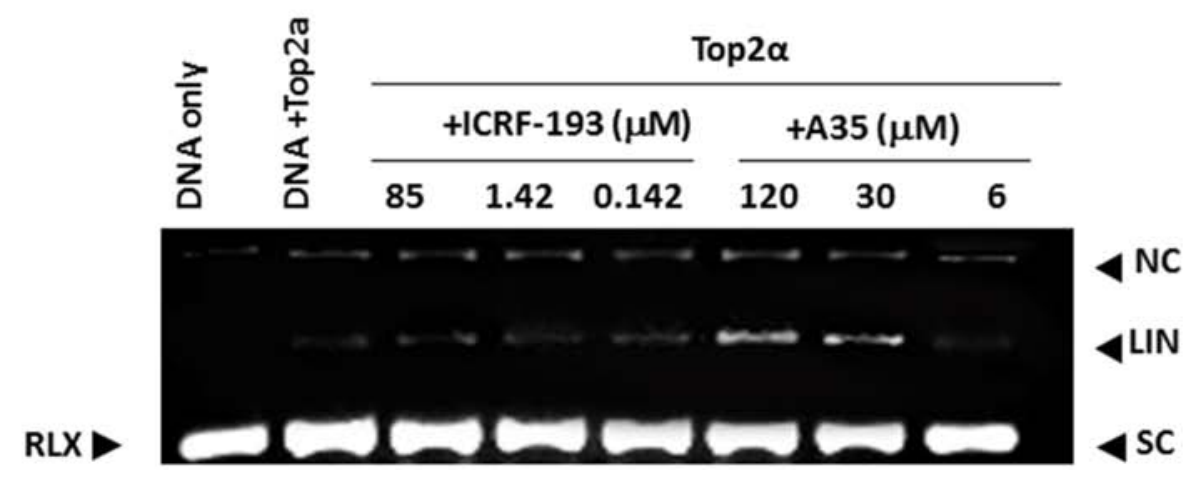

Figure 3: A35 induces top2 $\alpha$-DNA cleavage complex formation by enhancing pre-strand and post-strand cleavage and inhibiting DNA religation. A. The supercoiled plasmid pBR322 was incubated with purified top $2 \alpha(8 \mathrm{U})$ with or without the indicated concentrations of A35. Reaction products were separated by $1.4 \%$ agarose gel electrophoresis in the presence of the nucleic staining agent EB to allow for the separation of supercoiled (SC), relaxed closed-circular (RLX), linear (LIN) and nicked circular (NC) DNA. The intensities of the linear bands observed were quantified and plotted relative to the control (pBR322+Top2 $\alpha$ ).

(Continued) 


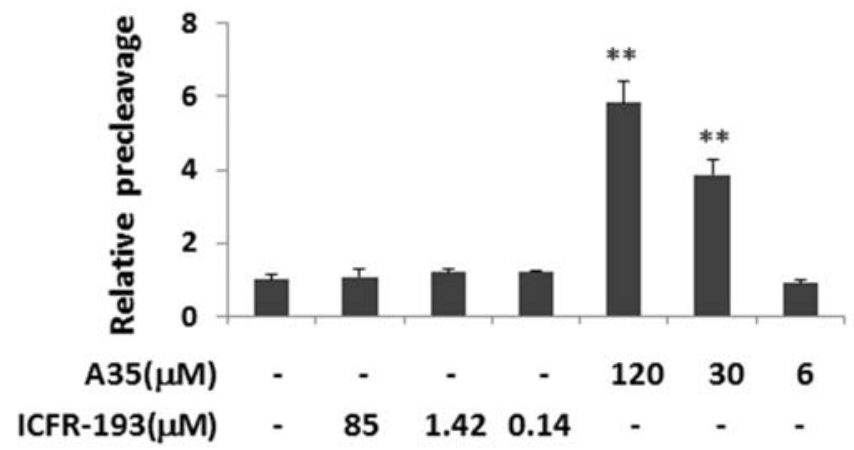

C
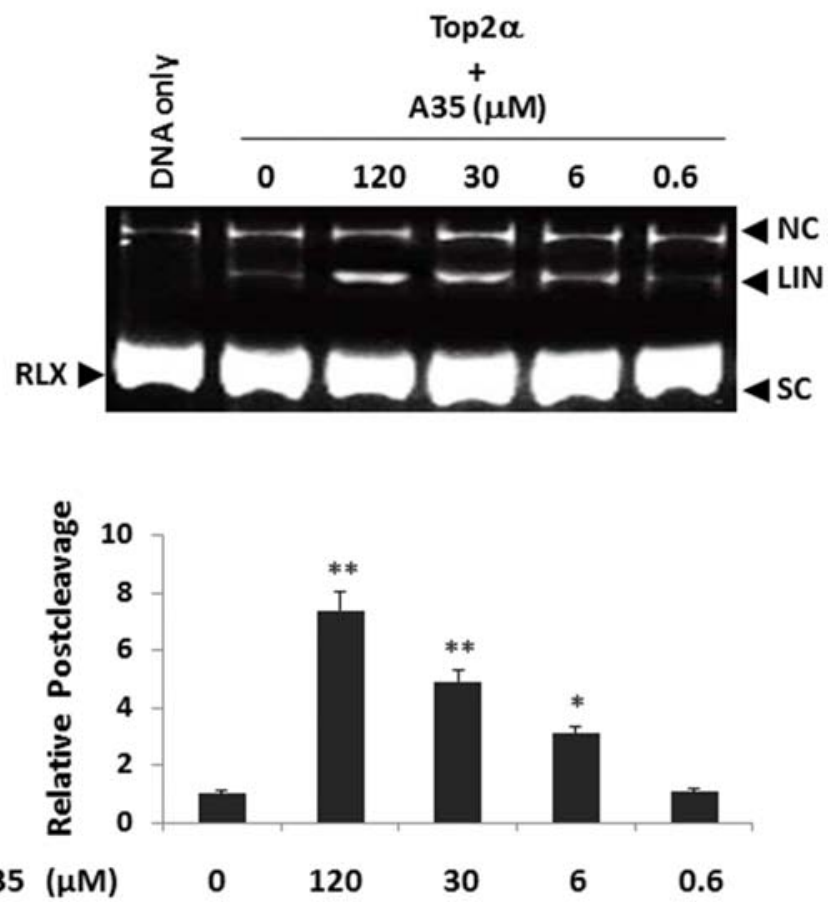

D

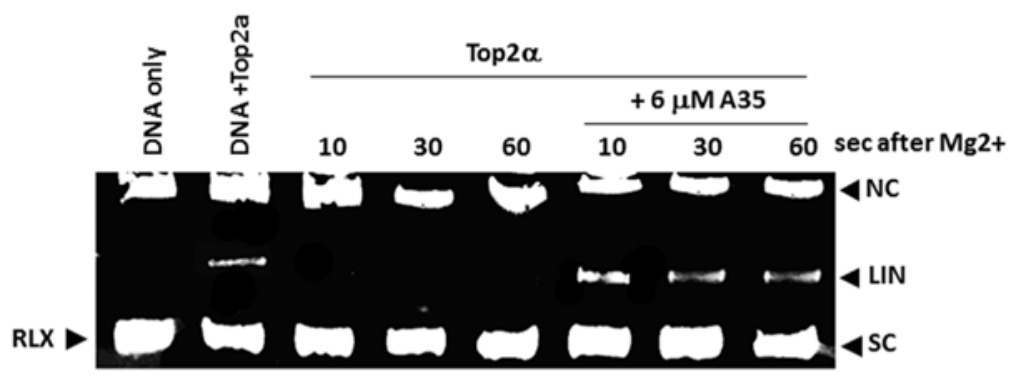

Figure 3 (Continued): B. To determine the effects of A35 on top $2 \alpha$-mediated pre-strand passage cleavage, reactions were performed in the absence of ATP, and the intensities of the linear bands were quantified and plotted relative to the control (pBR322DNA+Top2 $\alpha$ ). C. Top2 $\alpha$-mediated post-strand passage DNA cleavage affected by A35 was carried out in a reaction buffer containing AMPPNP $(1 \mathrm{mM})$ instead of ATP, and the resulting graph was constructed. D. Top $2 \alpha$-mediated religation of the pBR322 plasmid was examined in the presence or absence of A35. Kinetically competent top2-DNA complexes were trapped in the presence of $\mathrm{Ca}^{2+}$ and in the absence of ATP. After the addition of A35, reactions were reinitiated with $\mathrm{Mg}^{2+}$ and trapped at the indicated time points and examined. ${ }^{*} P<0.05 ; * * P<0.01$ 
and strand passage steps, had no effects on the formation of cleaved DNA or on the levels of nicked circular DNA in the pre-cleavage stage as a negative control.

To determine if A35 has similar effects on post-strand passage DNA cleavage, we repeated the above experiment, but with the addition of Adenylylimidodiphosphate(AMPPNP) in the reaction buffer [34]. The addition of this non-hydrolyzable ATP analog permits strand passage to occur. In the presence of AMPPNP and $\mathrm{Mg}^{2+}$, incubated with increasing concentrations of A35 led to cleaved DNA increased (Figure 3C), and indicated that A35 also prompted post-strand cleavage complex formation.

We subsequently examined the effects of A35 on top $2 \alpha$-mediated DNA religation. We kinetically trapped top2 $\alpha$-DNA complexes in the presence of $\mathrm{Ca}^{2+}$. After using EDTA to chelate the excess $\mathrm{Ca}^{2+}$ ions, $\mathrm{Mg}^{2+}$ reintroduction triggered the religation of the linear band [20]. To examine whether A35 impacts the religation of DNA by top $2 \alpha$, we initiated reactions with $\mathrm{Mg}^{2+}$ in the presence or absence of A35 (Figure 3D). The experiments demonstrated that the religation of DNA occurred almost immediately and was severely hindered by the addition of A35. Together, these results indicated that A35 could enhance top $2 \alpha$-mediated prestrand and post-strand DNA cleavage and inhibit DNA religation.

\section{Compared with top1, top $2 \alpha$ is preferentially and specifically targeted in A35-induced cell DNA strand breaks, top-DNA covalent complexes and growth inhibition}

Although the cell-free assay showed that A35 was a dual inhibitor against top 1 and top $2 \alpha$, true target identification should be obtained in a cell assay. First, we used K562, HL60, Raji and Romas hematological tumor cells as well as solid tumor cells including the hepatic carcinoma cell lines HepG2, Bel7402 and Bel7404 and colorectal cancer cell lines to evaluate the growth inhibitory effects of A35. The results showed that the IC50 for all cancer cells except for Bel7404 was less than $2 \mu \mathrm{M}$, indicating good proliferation inhibitory activity (Figure 4A). Given that the cell-free assay showed that A35 induce top 1 and top $2 \alpha$ mediated DNA single or double DNA cleavage, we examined DNA single strand breakage with an alkaline comet assay [35] and double strand breakage with a neutral comet assay in cells treated with A35. The results showed that A35 could induce single strand DNA breakage, and at $1.2 \mu \mathrm{M}$ the tail moment (TM) was about 1.5 folds of control, and at higher concentrations $(6 \mu \mathrm{M}$ and $10 \mu \mathrm{M})$ the tail moments were approximately 3 -fold of the control (Figure 4B, upper). Neutral comet electrophoresis indicated that $\mathrm{A} 35$ could induce obvious DNA double breakage at each concentration and in a dose-dependent manner: at the lowest concentration of $1.2 \mu \mathrm{M}$, the tail moment was approximately 9-fold of the control, and at $6 \mu \mathrm{M}$ and $10 \mu \mathrm{M}$ the tail moments were up to 30 -fold of the control, indicating that A35 induced more double strand breakage (Figure 4B, lower).

The cell-free assays showed that A35 could induce DNA-top1 or -top $2 \alpha$ complex formation. We then utilized the TARDIS (trapped in agarose-DNA immunostaining) assay to further clarify the effects in cells. As shown in Figure 4C, top1-DNA and top2 $\alpha$ DNA complexes were observed in a dose-dependent manner after treatment with $\mathrm{A} 35$, and at $6 \mu \mathrm{M}$ the top $2 \alpha$-positive cells were up to $80 \%$ and top1-positive cells were approximately $20 \%$ of the total. However, we did not visualize the top $2 \beta$-DNA complex at any concentration of A35. To further ascertain top $2 \beta$ is not the target of $A 35$, we performed top $2 \beta$-mediated DNA cleavage assay in the presence of A35 to evaluate the effect of A35 on DNA cleavage, and results also demonstrated that A35 did not lead to DNA breakage mediated by top $2 \beta$ and the positive (VP16) control induced significant DNA breakage (Figure 4D), indicating A35 did not target top2 3 .

To verify top 1 and top $2 \alpha$ are the primary target of A35 to induce DNA breakage followed by cell death, we knocked down top1, top $2 \alpha$ and top $2 \beta$ and further assessed whether A35-induced cell proliferation inhibition and DNA breakage that was lethal to cell survival could be reversed,. As shown in Figure 4E, the topoisomerases were knocked down, and we found there was a compensatory effect between top 1 and top $2 \alpha$, specifically that when top 1 decreased top $2 \alpha$ would increase and vice-versa. However, in the top $2 \beta-$ silenced cells, there were only minor changes in top $2 \alpha$ and top 1 levels. To these topoisomerase knockdown cells, we added $2 \mu \mathrm{M}$ A35 for 24 hours and evaluated levels of the double-strand break (DSB) damage marker $\gamma-\mathrm{H} 2 \mathrm{AX}$. The results showed that $\gamma-\mathrm{H} 2 \mathrm{AX}$ levels increased in top 1 knockdown cells and decreased in top $2 \alpha$ knockdown cells, but obvious changes were not detected in top $2 \beta$ knockdown cells (Figure 4E). Then, we examined the effects of A35 on cell proliferation after topoisomerase silencing, and the results showed that with the knockdown of top1, the proliferation inhibitory activity induced by A35 was strengthened but was reversed after top $2 \alpha$ was silenced, and there was no significant change in top $2 \beta$-silenced cells (Figure 4F). The alkaline and neutral comet assays also showed that in top1-silenced cells, single and double strand DNA breakage all increased, while in top $2 \alpha$-silenced cells single and double strand DNA breakage decreased (Figure 4G). These results indicated that top 1 and top $2 \alpha$ were all targets of A35, but top $2 \alpha$ was a more vital target and $\mathrm{A} 35$ did not target top $2 \beta$. 
A35 does not induce cardiac cell cytotoxicity and mitochondrial damage and induces cancer cell apoptosis but not through the mitochondrial pathway

Currently, topoisomerase 2 inhibitors are effective antineoplastic agents and have been widely used in tumor therapy. However, given their adverse effects, the application of topoisomerase 2 inhibitors, especially anthracyclines such as doxorubicin (DOX), has been restricted primarily due to the serious cardiac toxicity that results from targeting top $2 \beta$. Although the above cell-free and cell-based assays verified that A35 could not target top $2 \beta$, for further verifying the non-cardiotoxic effects

A

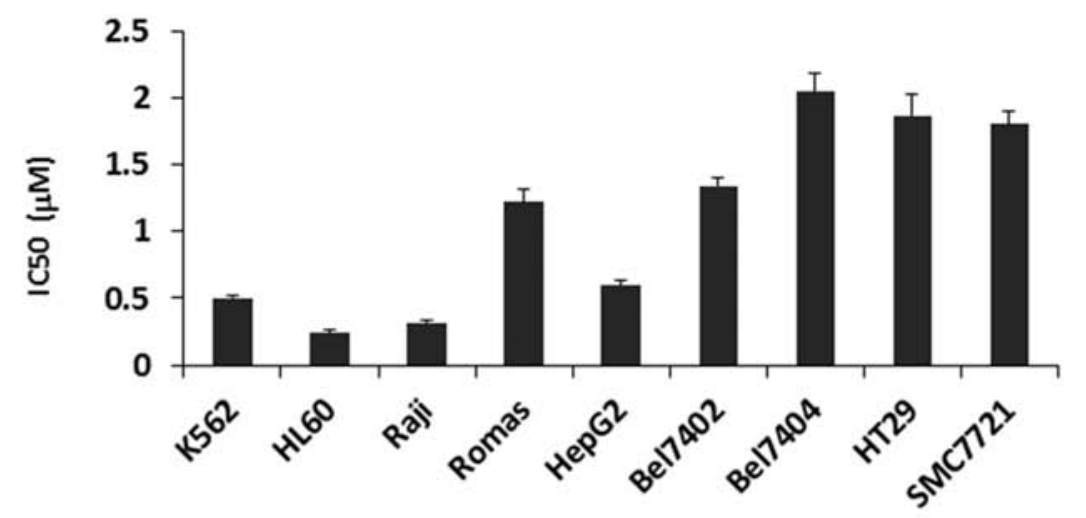

B
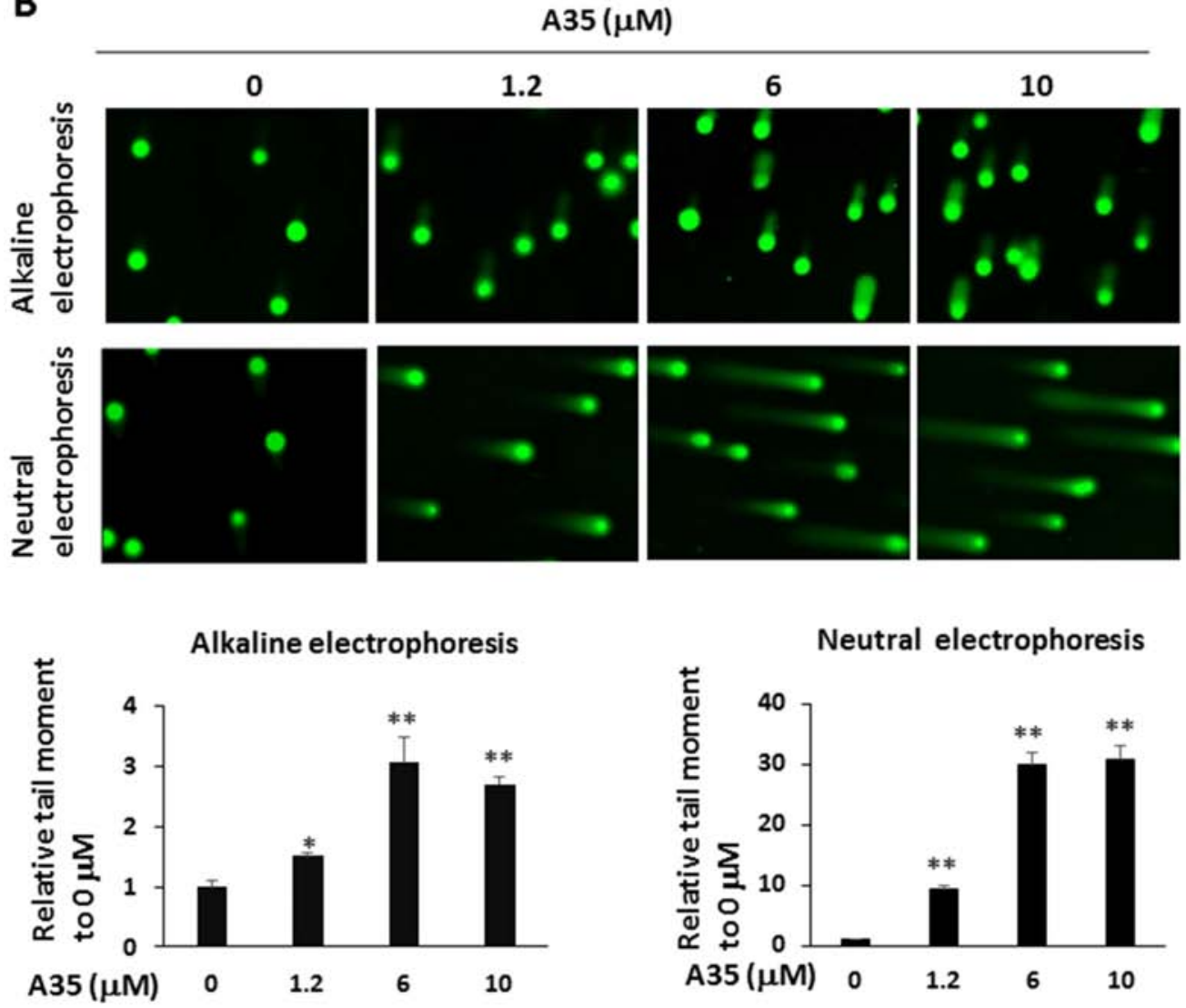

Figure 4: Compared with top1, top2 $\alpha$ was preferentially and specifically targeted in A35-induced cell DNA strand breaks, top-DNA covalent complexes and growth inhibition. A. IC50 of A35 in various cancer cells. Cells were treated with different concentrations of A35 for 48 hrs, and IC50 was evaluated with SigmaPlot. B. K562 cells were treated for 1.5 hours in the presence of A35, and cells were collected and alkaline comet electrophoresis and neutral comet electrophoresis assays were performed. The quantitative analysis was performed with the comet analysis software CASP, and the parameters TM (tail moment) was employed to evaluate DNA damage. Assays were repeated three times and the mean value of TM was normalized to the control $(0 \mu \mathrm{M})$.

(Continued) 
C
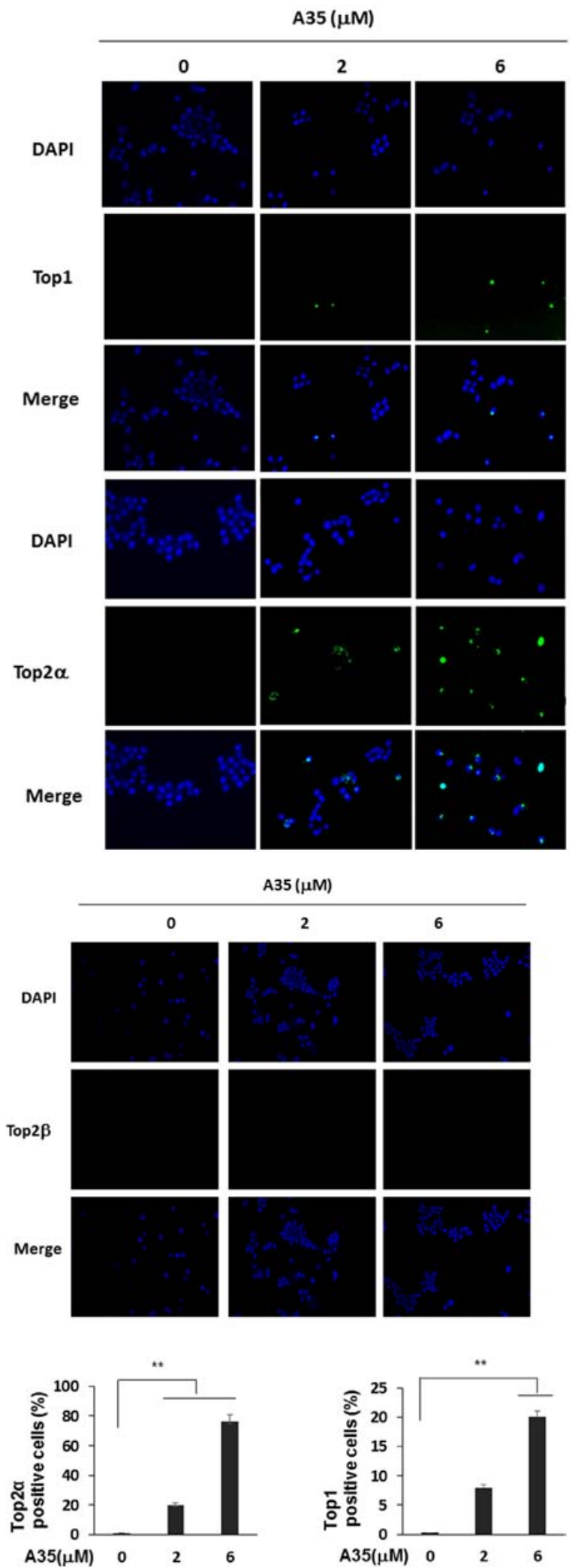

Figure 4 (Continued): C. K562 cells were treated with increasing concentrations of A35 for 1.5 hours, and the formation of DNA-top covalent complexes was analyzed by TARIDS assay. Nuclei were counterstained with DAPI. The histogram shows the percentage of top $2 \alpha$-positive or top1-positive cells. The results of a single experiment are shown; 50 nuclei were analyzed in each assay. 
D

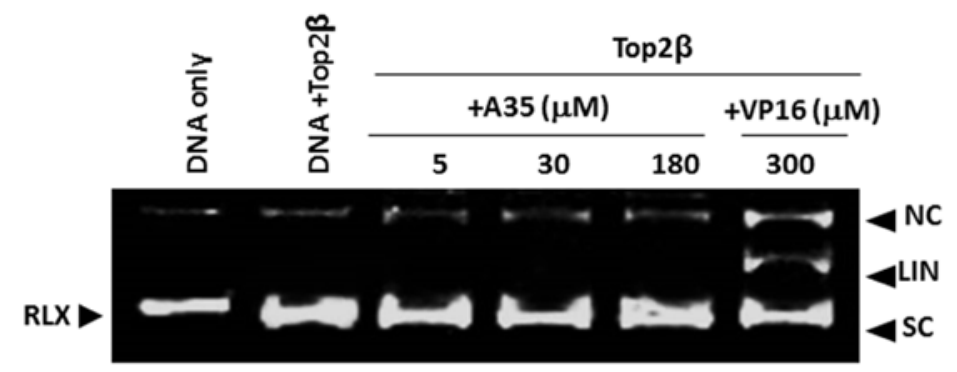

$\mathbf{E}$

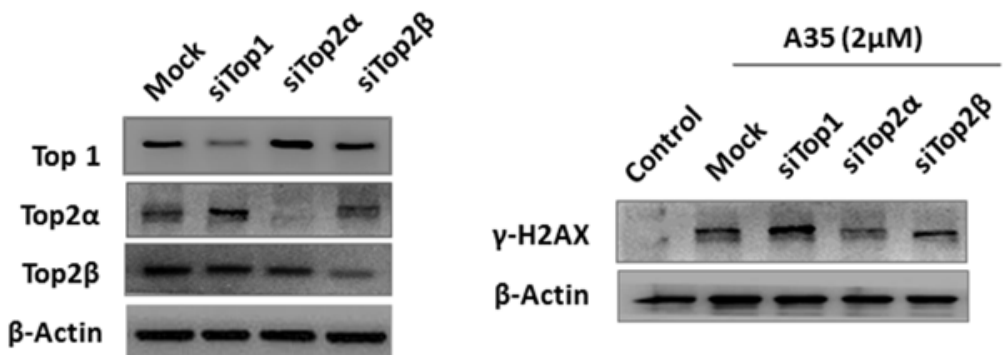

$\mathbf{F}$

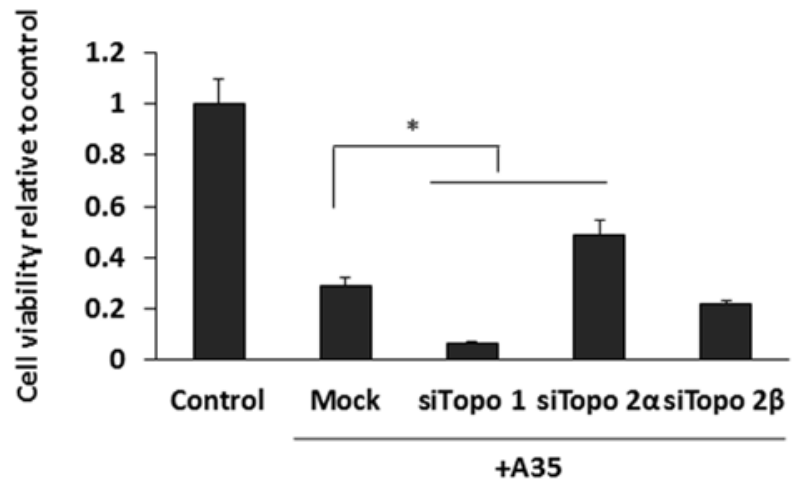

G

A35

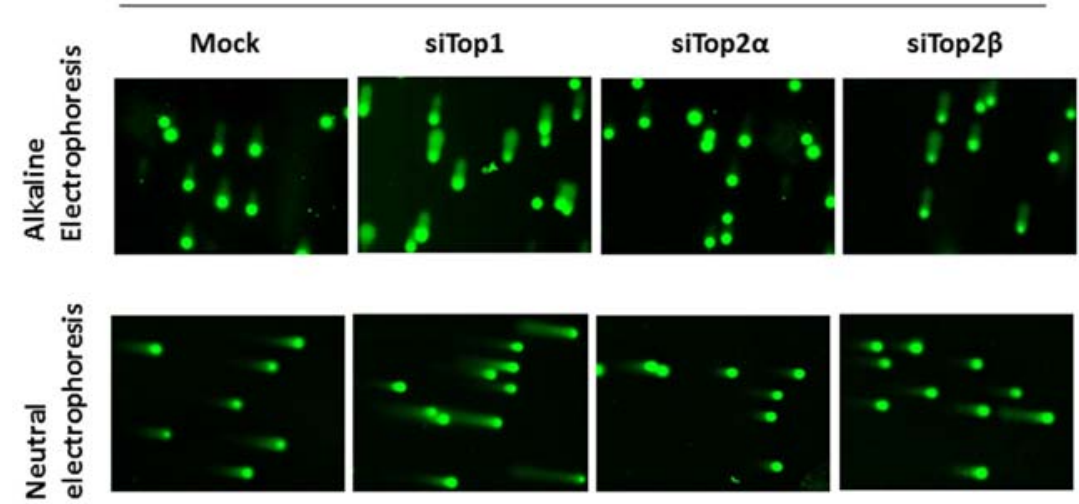

Figure 4 (Continued): D. The DNA pBR322 was incubated with purified top2 $\beta$ with or without the indicated concentrations of A35 or VP16. Reaction products were separated by $1.4 \%$ agarose gel electrophoresis in the presence of the nucleic staining agent EB. K562 cells were transfected with top1 or top2 siRNA for 48 hours, and top1 and top2 levels were detected E. $1.2 \mu \mathrm{M}$ A35 was then added into the top1 or top2 silenced cells and incubated for 24 hours to examine $\gamma$-H2AX levels (E) and cell survival F. Incubation for 1.5 hours to detect DNA single or double strand breakages via alkaline or neutral comet electrophoresis

(Continued) 

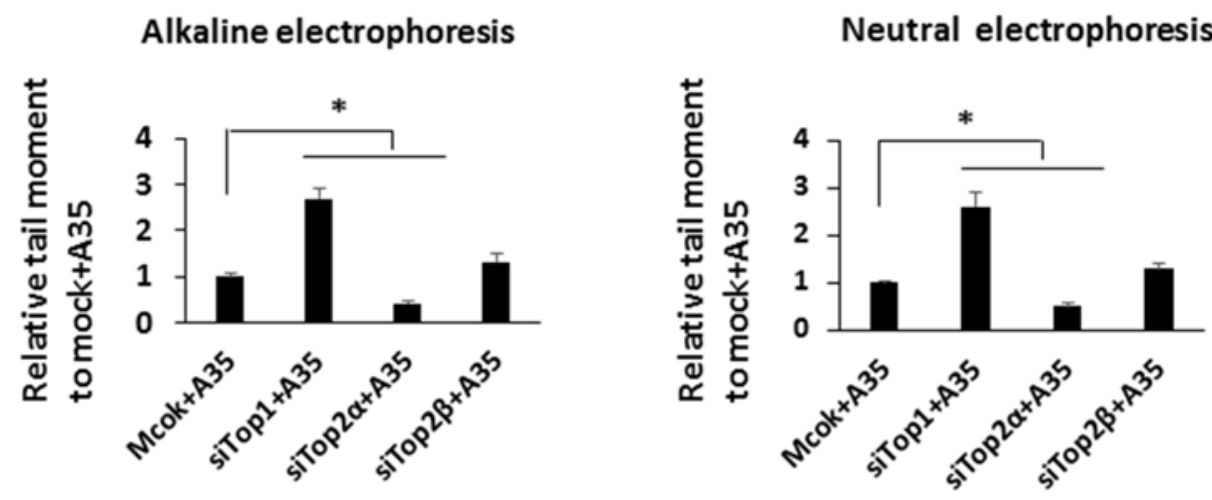

Figure 4 (Continued): G. $* P<0.05 ; * * P<0.01$

of $\mathrm{A} 35$ we utilized $\mathrm{H} 9 \mathrm{C} 2$ cardiac myoblasts from rats to perform the following assays. First, we evaluated whether A35 exerted proliferation inhibitory effects on $\mathrm{H} 9 \mathrm{C} 2$ cells, and the results showed that after $24 \mathrm{~h}$ treatment with $\mathrm{A} 35$, at the concentrations of $2 \mu \mathrm{M}$ and $5 \mu \mathrm{M}$ cell vitality was almost equal to the control, and at $10 \mu \mathrm{M}$ cell survival was approximately $90 \%$ of the control. After treatment for $48 \mathrm{~h}, \mathrm{H} 9 \mathrm{C} 2$ cell survival was approximately $90 \%$ of the control at $2 \mu \mathrm{M}$ and $5 \mu \mathrm{M}$ and $80 \%$ at $10 \mu \mathrm{M}$ (Figure 5A), indicating that A35 barely interfered with cardiac cell proliferation. However, in the doxorubicintreated group, we visualized obvious cardiac cell growth inhibitory effects after $24 \mathrm{~h}$ of treatment, and at $48 \mathrm{~h}$, most cells were dead at higher concentrations. Specifically, after $24 \mathrm{~h}$ treatment cell survival was $70.2 \%$ of the control at $2 \mu \mathrm{M}, 63.5 \%$ at $5 \mu \mathrm{M}$ and $53.2 \%$ at $10 \mu \mathrm{M}$, and after $48 \mathrm{~h}$ treatment cell survival was $40.3 \%$ at $2 \mu \mathrm{M}, 12.5 \%$ at $5 \mu \mathrm{M}$ and $7.3 \%$ at $10 \mu \mathrm{M}$. Similarly, after the addition of DOX for $48 \mathrm{~h}$, obvious apoptosis occurred, and the apoptotic cells were approximately $45 \%$ at $2 \mu \mathrm{M}, 78 \%$ at $5 \mu \mathrm{M}$ and $85 \%$ at $10 \mu \mathrm{M}$, but there was only $7-12 \%$ apoptotic cells observed in the A35-treated group (Figure 5B).

A number of studies have suggested that mitochondrial dysfunction is the primary molecular mechanism underlying DOX-induced cardiotoxicity. Alterations in mitochondrial membrane potential were the main effects of DOX in the mitochondria. Recent studies showed that DOX-induced mitochondria dysfunction is entirely attributable to the targeting of mitochondria top2 $\beta$, leading to mitochondrial nucleic acid synthesis blockage and causing the collapse of membrane potential, finally leading to whole-cell energy supply obstruction and cell death $[14,36]$. We detected the effects of A35 on mitochondrial membrane potential with JC-1. JC-1 is a fluorescent dye that exhibits potential-dependent accumulation in the mitochondria and can selectively enter the mitochondria as J-aggregates (JC-1 aggregates) with intense red-orange fluorescence in normal cells. If the membrane potential is disturbed, the dye remains in the monomeric form as J-monomer, emitting only green fluorescence. In our experiments, shown in Figure 5C, red granular aggregates were observed in the cytoplasm after excitation at $488 \mathrm{~nm}$, both in untreated $\mathrm{H} 9 \mathrm{C} 2$ cells or cells treated with various concentrations of $\mathrm{A} 35$, indicating that A35 did not alter the mitochondrial membrane potential of $\mathrm{H} 9 \mathrm{C} 2$ cells. However, in doxorubicin-treated cells, at $2 \mu \mathrm{M}$ red granular aggregates obviously decreased in the cytoplasm, and at higher concentrations $(5 \mu \mathrm{M}$ and $10 \mu \mathrm{M})$, red fluorescence aggregates almost entirely disappeared, indicating that cell mitochondria membrane potency was dramatically destroyed. Given that top 2 was mainly located in the nucleus and doxorubicin itself emits red fluorescence, we observed red fluorescence in cells, particularly in the nuclei. Meanwhile, in the doxorubicintreated group, we observed cytoplasm that was distinctly wrinkled, distorted and broken. In comparison, the cytoplasm in A35-treated $\mathrm{H} 9 \mathrm{C} 2$ cells was plump both at low or high concentrations, indicating that A35 did not injure cardiac cells and their mitochondria.

Then, we examined the signal proteins associated with mitochondrial damage that lead to cell apoptosis. It was previously reported that activated p53 (phosphorylated at Ser 15) and p53 levels were important to induce cardiomyocyte mitochondrial damage and finally cell death [37], and p53 levels are usually dependent on the activation of MAPK family proteins such as p-38, ERK and JNK. In our experiment, the phosphorylation levels of p-38, ERK and JNK and p53 in H9C2 cells did not significantly change following the addition of A35, despite the fact that these protein levels were obviously elevated in the doxorubicin-treated group. The levels of downstream targeting protein of $\mathrm{p} 53$ such as Bcl-2 did not change in A35-treated cells (Figure 5D).

Annexin V-PI was used to evaluate the apoptosis or necrosis of tumor cells treated with A35, and the results indicated that the apoptotic cells were approximately $90 \%$ of total apoptotic and necrotic cells and increased in a dose-dependent manner (Figure 5E). We also observed the final apoptosis event in which PARP was cleaved after A35 treatment for 24 or 48 hours either in K562 or HepG2 cells (Figure 5F). Cleaved and activated caspase-7 that could cleave PARP was also detected after A35 addition. 
Usually, caspase-7 can be activated by mitochondrial caspase 9 or other non-mitochondrial caspases, but we did not observe cleavage and activation of caspase-9, whose activation represents mitochondrial apoptosis. The expression levels of the proteins that promote mitochondrial apoptosis pathway activation, such as Bax and p53 (although p53 is a mutant in K562 cells), were not increased in the presence of $\mathrm{A} 35$, and the expression of $\mathrm{Bcl}-2$, a protein that suppresses mitochondrial apoptosis pathway activation, did not change (Figure 5F).

\section{A35 suppresses tumor cell growth in vivo and demonstrates no toxicity in mouse hearts}

Next, in a tumor xenograft nude mouse model, we examined A35 anticancer efficacy and its effects on the mouse myocardium. The results indicated that A35 could suppress tumor xenograft proliferation, and at $20 \mathrm{mg} / \mathrm{kg}$ the inhibitory rate was approximately $55 \%$, while at $10 \mathrm{mg} / \mathrm{kg}$ the inhibitory rate was approximately $35 \%$ (Figure $6 \mathrm{~A}$ ). The body weight curves indicated that the animals tolerated well the A35 dosages administered (Figure 6B). When the tumor sizes reached $1000 \mathrm{~mm}^{3}$, the mice were sacrificed, and tumors and hearts were excised to be used for further analysis. Tumor tissue was prepared as frozen sections for $\gamma-\mathrm{H} 2 \mathrm{AX}$ detection and for a TUNEL assay to detect apoptosis. The results showed that $\mathrm{A} 35$ could significantly induce DNA double breakage, and $\gamma$-H2AX-positive cells increased to $40 \%$, and the TUNEL results indicated that A35 could induce tumor cell apoptosis and the apoptotic cells comprised up to approximately $70 \%$ of total cells (Figure $6 \mathrm{C}$ ), indicating an identical action mechanism as for the in vitro results.

\section{A}

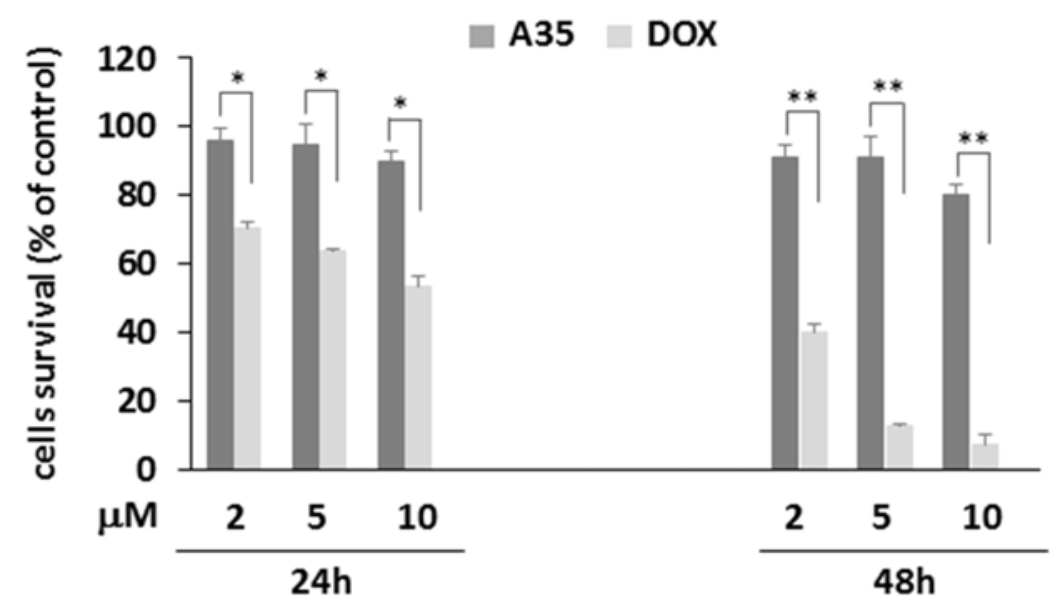

B

A35 DOX

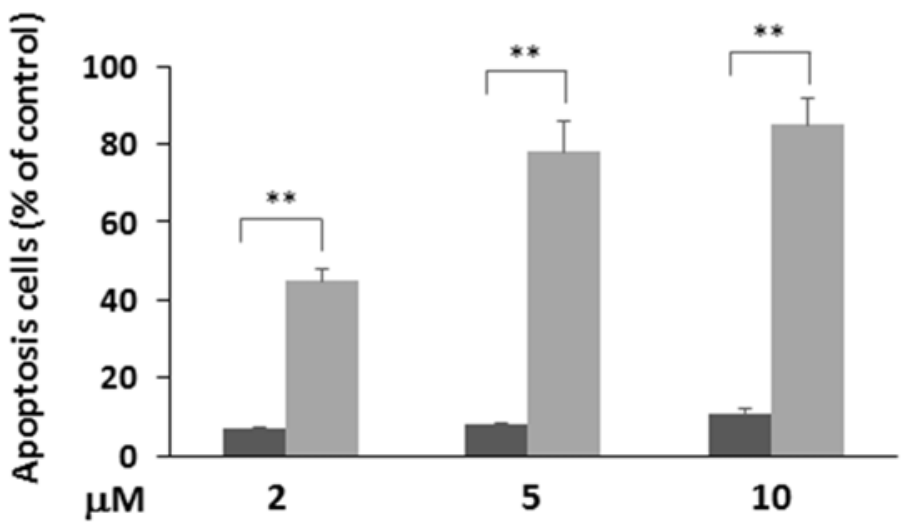

Figure 5: A35 does not induce cardiac cell cytotoxicity and mitochondrial damage and induces cancer cell apoptosis but not through the mitochondrial pathway. H9C 2 cells were treated with $2 \mu \mathrm{M}, 5 \mu \mathrm{M}$ and $10 \mu \mathrm{M}$ A35 or DOX for 24 or 48 hours, cell viability was detected by MTS A. and apoptosis was detected by Annexin V-FITC and PI-staining after 48 hours of treatment and the histogram was constructed and presented $\mathbf{B}$.

(Continued) 

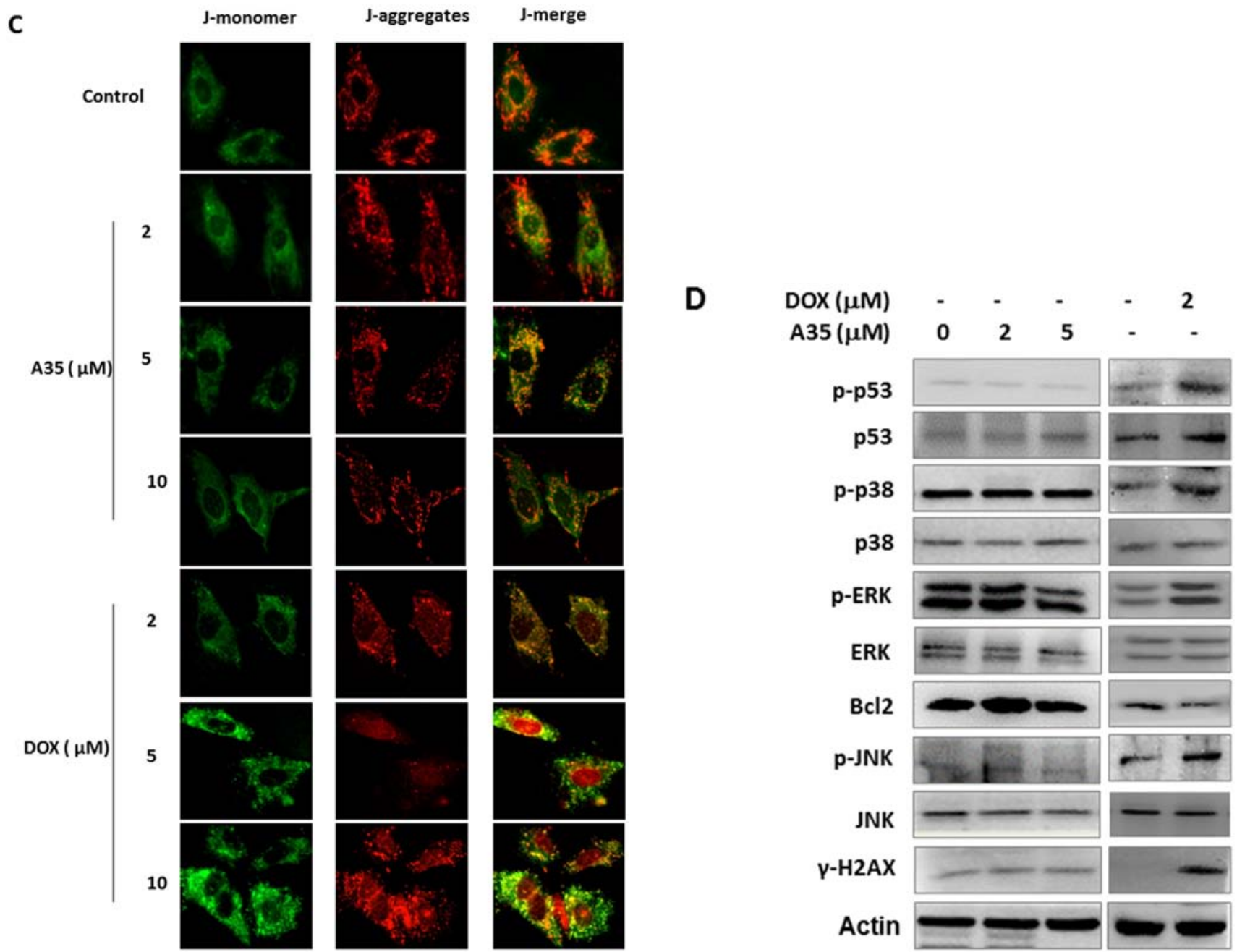

E

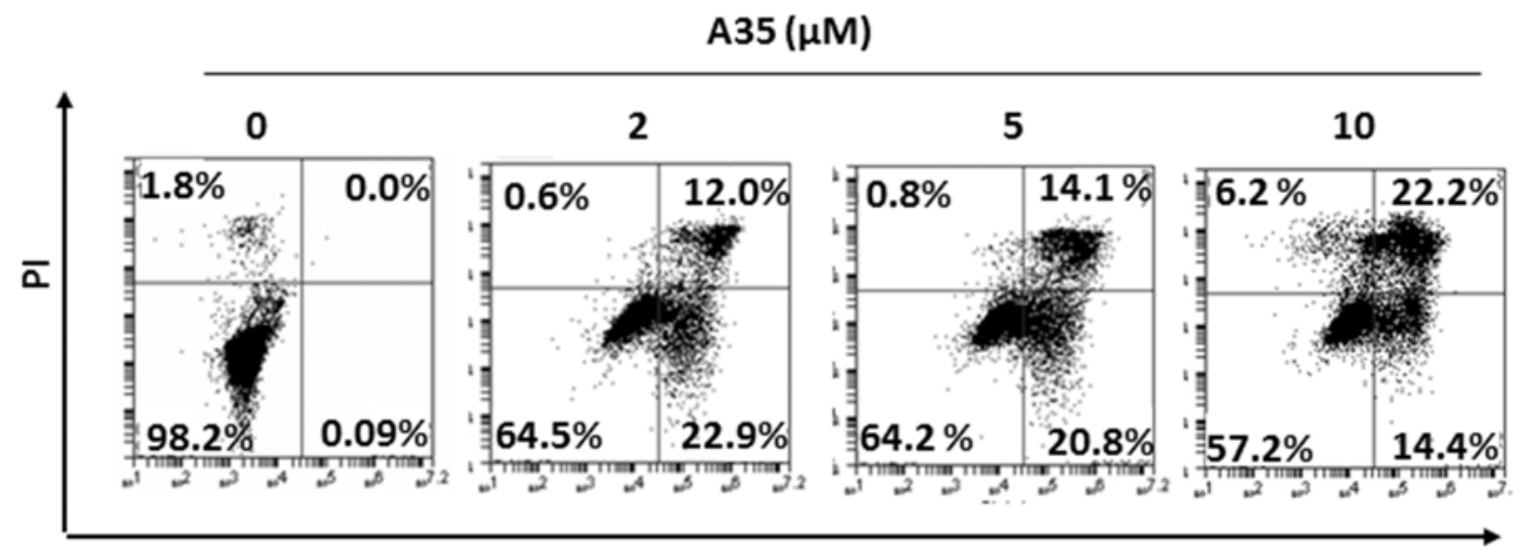

Figure 5 (Continued): C. H9C2 cells plated on coverslips were maintained in medium with or without $2 \mu \mathrm{M}, 5 \mu \mathrm{M}$ and $10 \mu \mathrm{M}$ A35 or DOX for $24 \mathrm{~h}$. Cells were stained with JC-1 and examined under fluorescence microscopy for red JC-1 aggregates or green JC-1 monomers, as described in the Materials and Methods. Typical images are shown. D. H9C2 cells were treated with indicated concentrations of A35 or DOX for 24 hours and mitochondrial damage-associated proteins or DNA damage proteins were measured by western blot. E. K562 cells were treated with increasing concentrations of A35 for 48 hours, and apoptosis was determined by flow cytometric analysis of Annexin V-FITC and PI-staining.

(Continued) 

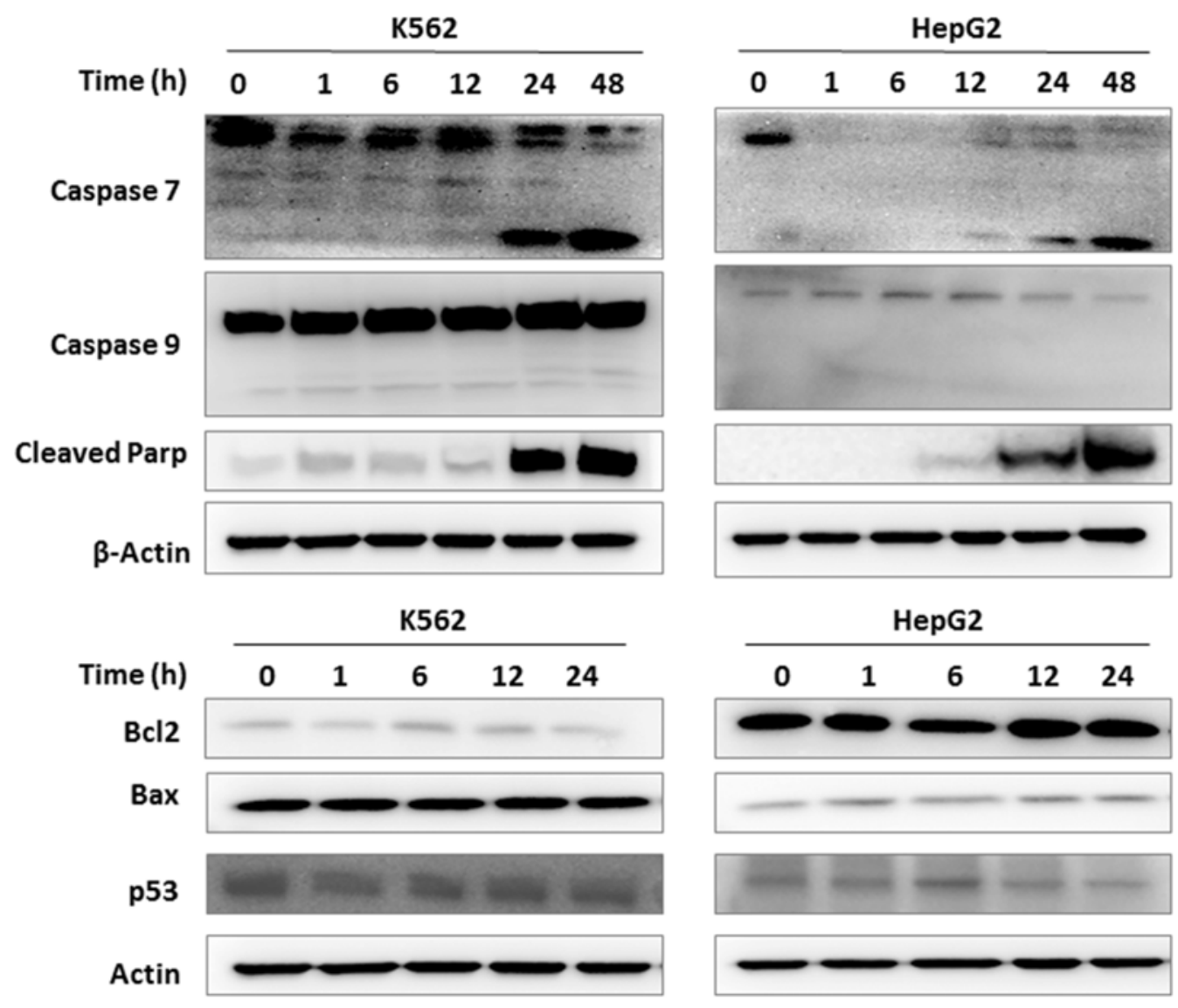

Figure 5 (Continued): F. K562 cells were treated by A35 and collected at the indicated time points for western blot analysis of apoptosis-associated proteins controlled by the mitochondria. ${ }^{*} P<0.05 ; * * P<0.01$ compared with DOX.

Cardiac toxicity detection was performed with frozen cardiac tissue sections for H\&E staining, $\gamma$-H2AX immunofluorescence and the TUNEL assay. H\&E results showed that in both the vehicle- and A35-administered groups, the myofibrils all arranged normally, but in the positive control, the DOX-treated group, the myocardial fibers shrank, were distorted and irregularly arranged and the myoplasm significantly lessened (Figure 6D). The TUNEL results corresponded to the H\&E results: in the vehicle and A35 groups, apoptotic cells were not observed, but in the DOX group approximately $80 \%$ of cells were apoptotic and approximately $40 \% \gamma-\mathrm{H} 2 \mathrm{AX}$-positive cells were observed (Figure 6E).

\section{DISCUSSION}

Cyclizing-berberine A35 is a site 1 and 13 cyclizing berberine. The cyclizing endows this compound with more planar structures that induce intercalation into free DNA, and these aromatic rings enhance the potency of intercalation into topoisomerase [38-40]. This structure is similar to known top $2 \alpha$ inhibitor NK314 [22, 23]. After evaluating its effects on top 1 and top $2 \alpha$ activity, unexpectedly we found that not only could A35 inhibit top2 $\alpha$ but it had an effect on top1, indicating that it is a dual topoisomerase inhibitor and has distinct effects on topoisomerases from NK314. Previously, some studies demonstrated that decreased topoisomerase levels are a major mechanism underlying relapse [9] and verified the compensatory effects between top1 and top2, which were also verified in the present study. Additionally, some authors also proposed that a dual targeting topoisomerase might increase overall anti-tumor activity, given that top1 and top2 have overlapping functions in DNA metabolism [41]. Thus, the novel skeleton compound A35 as a dual targeting top 1 and top $2 \alpha$ inhibitor might have the potency to avoid resistance and produce more powerful anticancer activity.

Given top $2 \alpha$ is a more effective target based on its preferential expression in proliferating cells and as the sole enzyme to distort daughter chromosomes, and the stronger effects of A35 on top $2 \alpha$; we focused on studying the inhibitory effects of A35 on top $2 \alpha$. Top2 
A

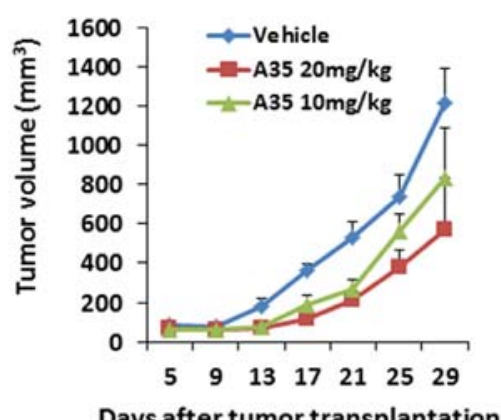

Days after tumor transplantation

C

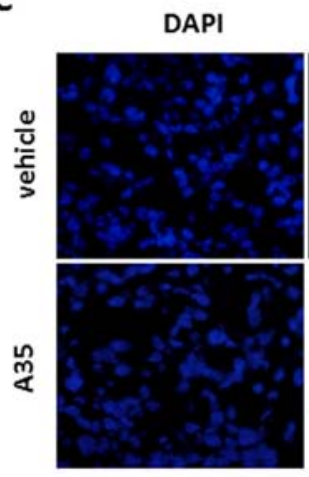

$\gamma-\mathrm{H} 2 \mathrm{AX}$
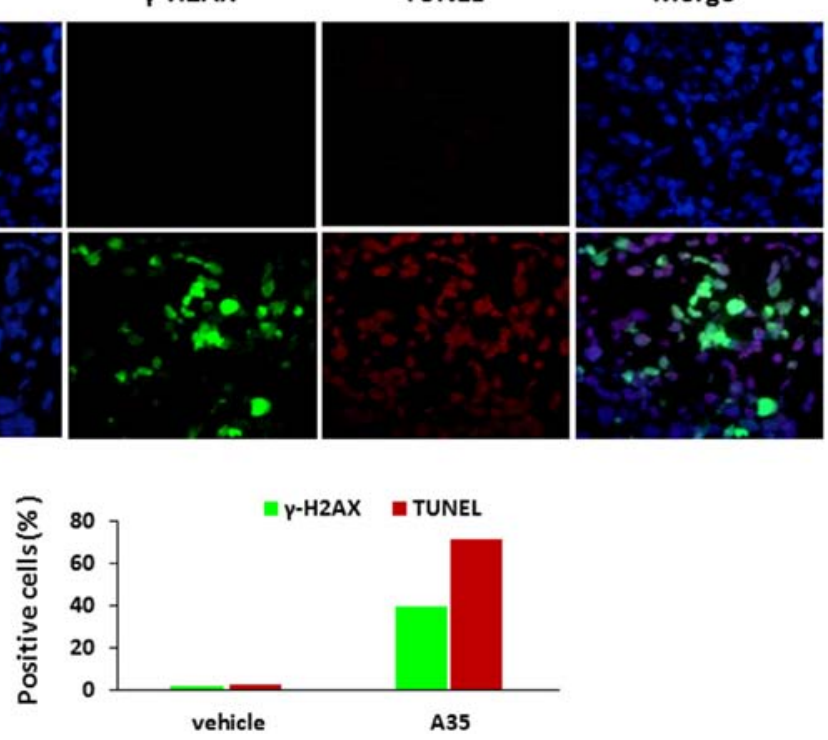

D

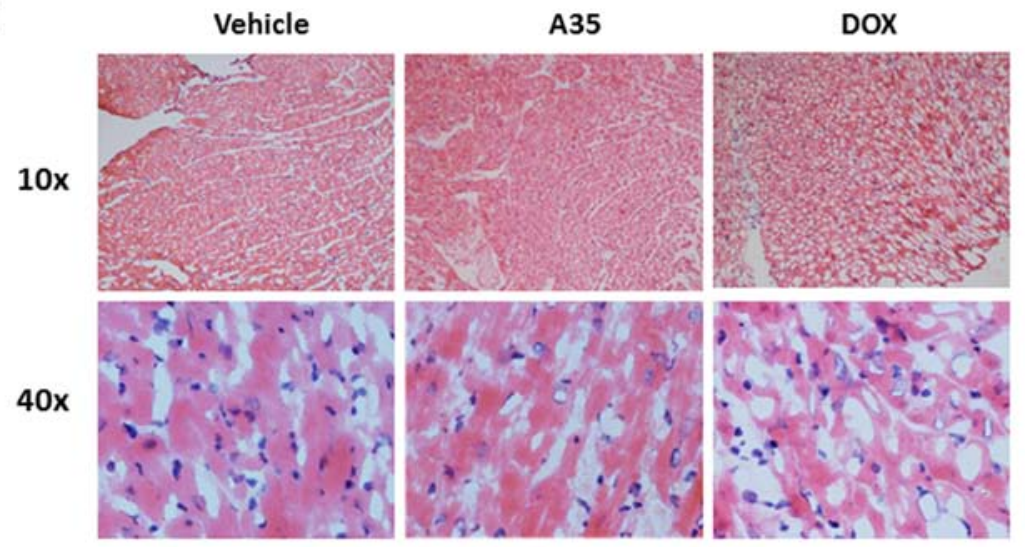

Figure 6: A35 suppresses tumor cell proliferation in vivo and has no toxicity in mouse hearts. Nude mice $(n=5)$ bearing HepG2 xenografts were administered A35 on day 8 after tumor inoculation and successively administrated A35 for 21 days once per day. Mice were sacrificed when the tumor volume of the control group reached $1000 \mathrm{~mm}^{3}$; the tumor loads and hearts were isolated and prepared as frozen cardiac sections. A. Tumor volume was measured by calipers twice per week in the indicated days. B. Body weights of mice harboring tumors were monitored twice per week in the indicated days. C. $\gamma$-H2AX immunofluorescence and TUNEL staining of frozen tumor sections from various treatment groups; the total numbers of $\gamma$-H2AX-positive nuclei or TUNEL-positive nuclei as a percentage of the total number of nuclei are shown in the bar graph. $n=5$ mice per group. D. H\&E staining of frozen cardiac sections from various treatment groups. 


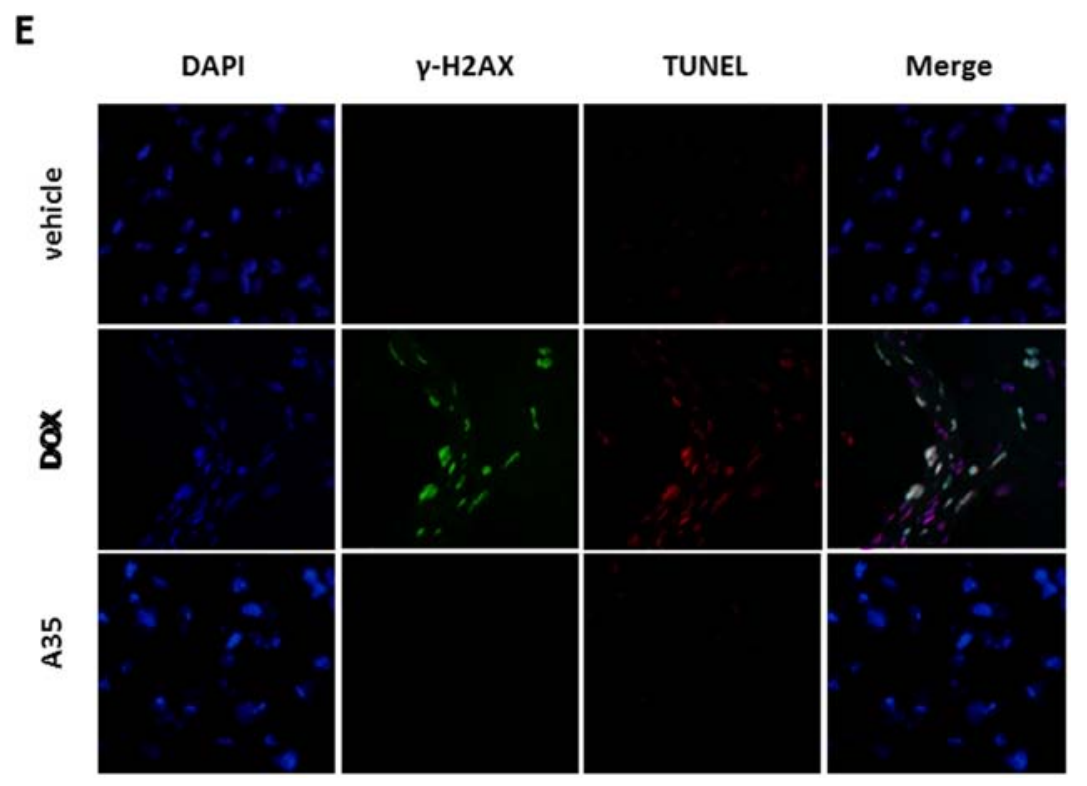

Figure 6 (Continued): E. $\gamma-\mathrm{H} 2 \mathrm{AX}$ immunofluorescence and TUNEL staining of frozen cardiac sections from various treatment groups.

manipulates DNA topology in an ATP-dependent manner via the mechanism known as the "catalytic cycle". The interruption of any step in the catalytic process might obstruct enzyme activity. Our results showed that although A35 could intercalate into DNA, it did not disrupt the top $2 \alpha$-DNA interaction. The ATP hydrolysis assay also demonstrated that A35 did not block top $2 \alpha$ ATPase activity. Cleavage assays demonstrated that A35 could stabilize the intermediate DNA-top $2 \alpha$ complex by exerting its actions both in pre-strand and post-strand cleavage steps and inhibiting religation. Considering all the results above mentioned, Its mechanism is distinct from other known top $2 \alpha$ inhibitors, such as etoposide, which only has a very low affinity for intact DNA and only inserts into DNA cleavage sites and inhibits DNA religation $[42,43]$, and doxorubicin, which at low concentrations $(<1 \mu \mathrm{M})$ only inhibits DNA religation and at higher concentrations $(>10 \mu \mathrm{M})$ it interferes with top2 binding to DNA to exert anticancer effects [44]. Other reported inhibitors, such as the quinolone CP-115, the ellipticines, azatoxins, and the natural flavonoid genistein, either strengthen pre-strand or post-strand cleavage to facilitate top-DNA complex formation [45].

The A35 parental core berberine was reported to inhibit top1 [46] and in our lab we did not observe any inhibitory effects on top 1 or top $2 \alpha$ at concentration up to 80 $\mu \mathrm{M}$ (data not shown), a concentration at which A35 could obviously suppress top 1 and top $2 \alpha$ activity, indicated a higher topoisomerase inhibitory activity than berberine. Although some studies showed that berberine structural analog 5,6-dihydrocoralyne possessed inhibitory activity against top1 and top2, they did not clarify the effect on top2 isoforms [47, 48]. Berberine and its structural analog trigger mitochondria-dependent apoptosis of cancer cells, and studies also found that mitochondria membrane potential was severely destroyed [27, 49]; meanwhile, p53 was activated, levels of Bax, which can trigger mitochondrial caspase activation, increased and inhibitory protein $\mathrm{Bcl} 2$ levels decreased [27, 50, 51]. However, in A35-treated cancer cells, although apoptosis appeared, the mitochondria apoptosis pathway was not activated, which indicated the distinct mechanism from its parental core berberine in apoptosis induction. Usually except mitochondria caspase9, some non-mitochondrial caspases such as caspase-2, caspase- 8 and caspase 10 also play key role in activating effector caspase-7 [52], thus we speculate A35-induced caspase- 7 activation and subsequent apoptosis might be a result of activation of non-mitochondrial caspases. This also arouses our interest and in the following study we will continue working on this issue.

Human top $2 \alpha$ and top $2 \beta$ share very similar catalytic activities and are highly conserved, with $78 \%$ amino acid identity [53]; many agents targeting top $2 \alpha$ also interfere with top $2 \beta$, such as doxorubicin. However, as the sole enzyme present in heart tissue, the targeting of top $2 \beta$ would disrupt the normal catalytic cycle of top $2 \beta$ and then cause DNA DSB formation and mitochondria destruction, and damage to these organelles would activate the mitochondria apoptosis pathway mediated by $\mathrm{p} 53$, which underlies so-called cardiac toxicity [14]. Some reports have also demonstrated that embryonic fibroblasts lacking top $2 \beta$ were better protected against doxorubicin-induced cytotoxicity [54], and top $2 \beta$ deletion mice better prevented doxorubicin-induced cardiomyopathy [5]. Another advantage of only targeting top $2 \alpha$ and not targeting top $2 \beta$ is the potential to avoid secondary malignancies. Top $2 \beta$ has been suggested as a major culprit in the development of secondary malignancies [55]. Currently, many novel 
compounds have also been demonstrated to specifically target top $2 \alpha$, but these data were only from cell-free assays, i.e., compound, extracted topoisomerase enzyme and DNA plasmid directly reacted in buffer. However, validation with cardiomyocytes and animal hearts has not been reported. In our study, not only did we confirm the target in a cell-free assay but also using rat $\mathrm{H} 9 \mathrm{C} 2$ cardiomyocytes and nude mice, and we demonstrated that A35 did not induce DNA breakage, mitochondrial injury, apoptosis and p53-mediated mitochondrial apoptosis pathway activation in cardiac cells, which are the main cellular alterations following the targeting of top $2 \beta$, although in the DOX-treated group the above-mentioned effects were all observed, which further indicated that there were no effects of A35 on top $2 \beta$ at the cellular and animal levels.

In summary, as a novel and DNA intercalative agent, A35 dually inhibits topoisomerase and preferentially and specially targets top $2 \alpha$. It acts as a poison to promote DNA-top complex formation and had no effect on other catalytic steps mediated by top $2 \alpha$. Its distinct mechanisms from other known poisons will be useful for its combination with other topisomerase inhibitors. Although A35 intensively induced cancer cell apoptosis, it did not trigger the apoptosis of cardiac cells and mouse hearts and did not damage the mitochondria either in cancer cells or cardiac cells. Its further exploration might be helpful to overcome top1 and top2 resistant and cardiac toxicity, A35 is a promising topoisomerase anticancer agent and worthy to further develop in future.

\section{MATERIALS AND METHODS}

\section{Reagents and cells}

ICRF-193, VP16 and mAMSA were purchased from Sigma-Aldrich. Anti- $\gamma-\mathrm{H} 2 \mathrm{AX}$, anti-phospho-p53 (Ser15), anti-p53, anti-phospho-p44/42MAPK (ERK1/2), anti-p44/42MAPK (ERK1/2), anti-phospho-p38 (Thr180/ Tyr182), anti-p38, anti-phospho-JNK (Thr183/Tyr185), anti-JNK, anti-caspase3, anti-caspase 7, anti-PARP, anti$\mathrm{Bcl} 2$ and anti-Bax antibodies were purchased from Cell Signaling Technology. The anti- $\beta$-actin antibody was obtained from Sigma-Aldrich, and peroxidase-conjugated goat anti-mouse or goat anti-rabbit secondary antibodies were purchased from ZSGQ-BIO Company. Antibodies against top1, top $2 \alpha$ and top $2 \beta$ were purchased from Abcam. pBR322 DNA and top1 were purchased from BEIJING LIUHE TONG TRADE CO., LTD. Recombinant human top $2 \alpha$ was purchased from Topogen. The comet assay kit was obtained from Trevigen.

\section{Cell lines}

Rat myoblasts $\mathrm{H} 9 \mathrm{C} 2$ were obtained from the Cell Center of the Institute of Basic Medical Sciences, Chinese Academy of Medical Sciences and Peking
Union Medical College. Other cell lines, such as K562, HL60, Raji, Romas, HepG2, Bel7402, Bel7404, HT29 and SMC7721, were either from Cell Center of the Institute of Basic Medical Sciences or from ATCC. K562, HL60, Raji and Romas cells were cultured in 1640 medium with 10\% FBS, while H9C2, HepG2, Bel7402, Bel7404, HT29 and SMC7721 were cultured in DMEM with $10 \%$ FBS.

\section{Topoisomerase-mediated DNA relaxation assay}

The DNA relaxation assay was based on a procedure described previously [56]. Briefly, $2 \mu$ of $10 x$ reaction buffer with $1 \mathrm{mM}$ ATP (top $2 \alpha$ ) or without ATP (top1), $0.5 \mu \mathrm{g}$ of supercoiled pBR322, and 1 unit of top $2 \alpha$ (Topogen) or top 1 and compound were mixed in a total of $20 \mu \mathrm{l}$ of reaction buffer. Relaxation was performed at $37^{\circ} \mathrm{C}$ for $30 \mathrm{~min}$ and stopped by the addition of $2.5 \mu \mathrm{l}$ of stop solution (100 mM EDTA, 0.5\% SDS, 50\% glycerol, $0.05 \%$ bromophenol blue). Electrophoresis was performed in a $1 \%$ agarose gel in $0.5 \mathrm{x}$ TBE at $4 \mathrm{~V} / \mathrm{cm}$ for $1.5 \mathrm{hr}$. DNA bands were stained with the nucleic acid dye EB and photographed with $300 \mathrm{~nm}$ UV transillumination. The DNA bands were qualified with software Image J. The percent of relaxed DNA was calculated as: $\left(\mathrm{R}-\mathrm{R}_{0}\right) /$ $\left(R_{\text {control }}-R_{0}\right)$, where $R$ is the intensity of relaxed DNA incubated with top $2 \alpha$ and compound, $\mathrm{R}_{0}$ is the intensity of relaxed DNA of pBR322 and $\mathrm{R}_{\text {control }}$ is the intensity of relaxed DNA incubated with top1. The IC50 was defined as the concentration of A35 that resulted in a 50\% reduction of relaxed DNA.

\section{Top1-mediated DNA cleavage}

DNA cleavage assays were performed as described previously [57-59] A 117-bp DNA oligonucleotide from Sangon Biotech encompassing the previously identified top1 cleavage sites identified in the 161-bp fragment from pBluescript SK(-) phagemid DNA was employed. This 117-bp oligonucleotide contains a single 5'-cytosine overhang, which was 3 '-end labeled by fill-in reaction with $\left[\alpha-{ }^{32} \mathrm{P}\right]$-dGTP in reaction 2 buffer (50 mMTris- $\mathrm{HCl}$, $\mathrm{pH} 8.0,100 \mathrm{mM} \mathrm{MgCl}_{2}, 50 \mathrm{mM} \mathrm{NaCl}$ ) with 0.5 units of DNA polymerase I (Klenow fragment, New England BioLabs). Unincorporated ${ }^{32} \mathrm{P}-\mathrm{dGTP}$ was removed using mini Quick Spin DNA columns (Roche), and the eluate containing the 3 '-end-labeled DNA substrate was collected. Approximately $3 \mathrm{nM}$ of radiolabeled DNA substrate was incubated with recombinant top1 (60U) in $20 \mu \mathrm{l}$ of reaction buffer $[10 \mathrm{mM}$ TrisHCl $(\mathrm{pH} 7.5)$, $50 \mathrm{mM} \mathrm{KCl}, 5 \mathrm{mM} \mathrm{MgCl}, 0.1 \mathrm{mM}$ EDTA, and $15 \mu \mathrm{g} / \mathrm{ml}$ $\mathrm{BSA}$ ] at $25^{\circ} \mathrm{C}$ for $30 \mathrm{~min}$ in the presence of various drug concentrations. The reactions were terminated by adding SDS ( $0.5 \%$ final concentration) followed by the addition of two volumes of loading dye $(80 \%$ formamide, $10 \mathrm{mM}$ sodium hydroxide, $1 \mathrm{mM}$ sodium EDTA, $0.25 \%$ xylene cyanol, and $0.25 \%$ bromophenol blue). Aliquots of each 
reaction mixture were subjected to $16 \%$ denaturing PAGE. Gels were dried and visualized by using a phosphoimager.

\section{Topoisomerase 1-mediated DNA unwinding assay}

To examine the effects of A35 on DNA intercalation, a top1-based assay was carried out according to the literature [20]. In brief, supercoiled plasmid pBR322 was firstly relaxed with recombinant human top1 (4 units) at $37^{\circ} \mathrm{C}$ for $30 \mathrm{~min}$. Subsequently, A35 or mAMSA was added to the reaction and incubated for a further $30 \mathrm{~min}$ at $37^{\circ} \mathrm{C}$. Reactions were stopped by the addition of SDS to a final concentration of $1 \% \mathrm{w} / \mathrm{v}$, and top 1 was digested by the addition of proteinase $\mathrm{K}(50 \mu \mathrm{g})$ and incubation for $1 \mathrm{~h}$ at $56^{\circ} \mathrm{C}$. Samples were resolved on a $1 \% \mathrm{w} / \mathrm{v}$ agarose gel in $0.5 \mathrm{x}$ TBE at $4 \mathrm{~V} / \mathrm{cm}$ for $2 \mathrm{hr}$ and stained with EB. The definition of the percent of relaxed DNA and IC50 was as described in the "Topoisomerase-mediated DNA relaxation assay" section in the Methods.

\section{Electrophoretic mobility shift assay}

The effect of A35 on the binding of top $2 \alpha$ to DNA was evaluated using an electrophoretic mobility shift (EMSA) kit (Invitrogen) as previously described [60] according to the manufacturer's protocol. Oligonucleotides containing a strong top 2 binding site corresponding to residues $87-126$ of the pBR322 plasmid were annealed, and $1 \mathrm{~nm}$ was incubated with nuclear extracts $(5 \mu \mathrm{g})$ from $\mathrm{K} 562$ cells in reaction buffer $(750 \mathrm{mM} \mathrm{KCl}, 0.5 \mathrm{mM}$ dithiothreitol, $0.5 \mathrm{mM}$ EDTA, $50 \mathrm{mM}$ Tris, $\mathrm{pH}$ 7.4) on ice for $30 \mathrm{~min}$. Then, the samples were electrophoresed on a $5 \%$ non-denaturing polyacrylamide gel at $100 \mathrm{~V}$ and $4^{\circ} \mathrm{C}$ in TBE buffer for $1.5 \mathrm{~h}$. DNA was stained with SYBR Green and detected by $300 \mathrm{~nm}$ UV transillumination. In A35-treated samples, A35 and nuclear extracts were first incubated for $10 \mathrm{~min}$ on ice prior to the addition of oligonucleotide probes, and incubation continued for 30 min on ice. In super shift experiments, an antibody against top2 was first incubated with nuclear extracts for $1 \mathrm{~h}$ on ice, and then $1 \mathrm{~nm}$ probes were added and incubation continued for $30 \mathrm{~min}$ on ice.

\section{ATPase assay}

ATPase activity of top $2 \alpha$ was examined by measuring the liberated phosphate of $\left[\gamma_{-}{ }^{32} \mathrm{P}\right]$-ATP by thin layer chromatography as previously described $[20,61]$. Briefly, top $2 \alpha$ ( 8 units) was incubated in reaction buffer A (Topogen) in the presence of $1.2 \mu \mathrm{g}$ pBluescript-KS(+) plasmid DNA and the indicated drug for $10 \mathrm{~min}$ at room temperature prior to initiating the reaction with the addition of $3 \mu \mathrm{Ci}$ of $\left[\gamma^{-32} \mathrm{P}\right]$-ATP (PerkinElmer; $3000 \mathrm{Ci} / \mathrm{mmol}$ ) and continued to incubate at $37^{\circ} \mathrm{C}$. Aliquots $(2 \mu \mathrm{l})$ were withdrawn at various time points $(0,5 \mathrm{~min}, 10 \mathrm{~min} .15 \mathrm{~min}$, $20 \mathrm{~min}$ ) and loaded onto pre-washed polyethyleneimine- impregnated cellulose plates (Sigma-Aldrich) and airdried. Reaction mixtures were resolved by developing plates with freshly prepared $\mathrm{NH}_{4} \mathrm{HCO}_{3}(0.4 \mathrm{M})$. Plates were air-dried and exposed to autoradiographic film. Spots corresponding to free phosphate were excised from the thin layer chromatography plates and quantified using a scintillation counter.

\section{Top2-mediated DNA cleavage}

DNA cleavage assay was performed by using a Top2 $\alpha$ Drug Screening Kit (Topogen), $0.2 \mu \mathrm{g}$ pBR322 DNA plasmid was incubated with top $2 \alpha$ or top $2 \beta$ which was obtained and purified as described previously [62] in $20 \mu \mathrm{l}$ of assay buffer at $37^{\circ} \mathrm{C}$ for $30 \mathrm{~min}$ in the presence or absence of A35 or etoposide. DNA cleavage products were trapped by the addition of $2 \mu 1$ of $10 \%$ SDS and $1.5 \mu \mathrm{l}$ of $10 \mathrm{mg} / \mathrm{ml}$ proteinase $\mathrm{K}$, and then incubation continued for $60 \mathrm{~min}$ at $56^{\circ} \mathrm{C}$ to digest top $2 \alpha$. The samples were mixed with $2.5 \mu \mathrm{l}$ of loading buffer and subjected to electrophoresis in $1.4 \%$ agarose containing $0.5 \mathrm{mg} / \mathrm{ml}$ EB at $12 \mathrm{~V}$ for $15 \mathrm{hr}$. All DNA forms were separated and migrated as follows: RLX, SC, LNR, and NC.

\section{ATP-independent pre-strand passage cleavage assay}

Top $2 \alpha$-mediated plasmid DNA cleavage in the absence of nucleotide triphosphate was performed as described with slight modifications $[56,63]$. Top $2 \alpha$ (8 $\mu$ nits) was incubated with $0.2 \mu \mathrm{g}$ of pBR322 with increasing concentrations of A35 or ICRF-193 in $20 \mu \mathrm{l}$ of reaction buffer. The final buffer contained $0.01 \mathrm{M}$ Tris $\mathrm{pH} 7.7,0.05 \mathrm{M} \mathrm{NaCl}, 0.05 \mathrm{M} \mathrm{KCl}$, $0.1 \mathrm{mM}$ EDTA, $0.005 \mathrm{M} \mathrm{MgCl}_{2}$ and $0.03 \mu \mathrm{g} / \mu \mathrm{l}$ bovine serum albumin. Reactions were incubated for $20 \mathrm{~min}$ at $37^{\circ} \mathrm{C}$ and terminated by addition of $2 \mu \mathrm{l}$ of $10 \%$ SDS, followed by addition of $1.5 \mu \mathrm{l}$ of $0.25 \mathrm{M}$ EDTA and continued to culture for $5 \mathrm{~min}$ at $37^{\circ} \mathrm{C}$. Then, reactions were digested with $8 \mu \mathrm{g}$ of proteinase $\mathrm{K}$ and incubated for $60 \mathrm{~min}$ at $56^{\circ} \mathrm{C}$. DNA products were separated on a $1.4 \%$ gel containing $0.7 \mu \mathrm{g} / \mu \mathrm{l}$ ethidium bromide.

\section{Post-strand passage cleavage assay}

A top $2 \alpha$-mediated post-strand passage cleavage assay was performed as described above for pre-strand passage cleavage with the exception that $1 \mathrm{mM}$ AMPPNP (Sigma) was added in the reactions [63].

\section{ATP-independent DNA religation assay}

Top2 $\alpha$-mediated religation of DNA in the absence of ATP was performed as described previously [20]. Top $2 \alpha$ (8 units) was incubated with $0.2 \mu \mathrm{g}$ of pBR322 plasmid DNA in a reaction buffer containing $0.01 \mathrm{M}$ Tris $\mathrm{pH}$ 7.7, $0.05 \mathrm{M} \mathrm{NaCl}, 0.05 \mathrm{M} \mathrm{KCl}, 0.1 \mathrm{mM}$ EDTA, $0.005 \mathrm{M} \mathrm{CaCl}_{2}$ and $0.03 \mu \mathrm{g} / \mu \mathrm{l}$ of bovine serum albumin for $10 \mathrm{~min}$ at 
$37^{\circ} \mathrm{C}$. Immediately after, various concentrations A35 or control were added, followed by the addition of $2 \mu \mathrm{l}$ of 0.1 M EDTA to the reactions. Then, the reactions were re-initiated by the addition of $0.1 \mathrm{M} \mathrm{MgCl}_{2}(2 \mu \mathrm{l})$ and transferred immediately onto ice. At the indicated time points $(15,30$ or 60 seconds), reactions were terminated by the addition of $1 \% \mathrm{w} / \mathrm{v}$ SDS and incubation continued at $37^{\circ} \mathrm{C}$ for $5 \mathrm{~min}$. The reactions were then incubated with proteinase $\mathrm{K}(8 \mu \mathrm{g})$ for $30 \mathrm{~min}$ at $56^{\circ} \mathrm{C}$. DNA products were separated on an agarose gel $(1.4 \% \mathrm{w} / \mathrm{v})$ containing ethidium bromide $(0.5 \mu \mathrm{g} / \mu \mathrm{l})$.

\section{Comet assay}

Top1- or Top2-mediated DNA breakage was measured with a neutral comet assay (Trevigen) for DSB detection or an alkaline comet assay for single-strand break detection as described in the manufacturer's procedures and the literature [64]. The treated cells were embedded in agarose on a slide and subjected to lysis followed by electrophoresis under neutral or alkaline conditions. During electrophoresis, the damaged and fragmented negatively charged DNA migrated away from the nucleus toward the anode. The amount of migrated DNA was a measure of the extent of DNA damage. To detect DNA, the slides were stained with SYBR Gold (Life Technology) staining solution. The slides were examined by fluorescence microscopy (Olympus), and the results were analyzed with the comet analysis software CASP to quantify DNA damage. For each drug concentration, 3 independent assays were conducted in which comet tails were analyzed in a minimum of 50 randomly selected cells in each assay, and parameter reflecting the DNA damage was represented as TM (tail moments, percentage of DNA in tail/tail length) [65].

\section{TARDIS assay}

The TARDIS assay is used to determine cleavable complex formation and has been described in detail [35]. Briefly, cells treated with various concentrations of A35 for $1.5 \mathrm{hr}$ were embedded in agarose on microscope slides and subjected to a lysis procedure that removed the cell membrane and soluble proteins in lysis buffer (1\% sarkosyl; $80 \mathrm{mM}$ phosphate, pH6.8; 10 mM EDTA plus protease inhibitors). To remove noncovalently bound nuclear proteins, cells were washed with $1 \mathrm{M}$ $\mathrm{NaCl}$ plus protease inhibitors. Then, slides were stained with primary antibody (specific for top 1 , top $2 \alpha$ or top $2 \beta$, with a dilution of $1: 200$ ) and a fluorescein isothiocyanate (FITC)-conjugated secondary antibody. Finally, the slides were mounted with an anti-quenching agent containing DAPI. Images were captured using a fluorescence microscope that separately visualizes green (FITC-stained) and blue (DAPI-stained) fluorescence.

\section{Small interfering RNA (siRNA)-mediated Gene knockdown}

Topoisomerase knockdown experiments were carried out in the same manner as described previously [66]. Small interfering RNAs (siRNAs) were synthesized by Ribo Technology Company using 2'-ACE protection chemistry. The sequences targeting top $1,2 \alpha$ and $2 \beta$ were, respectively, 5' GGACUCCAUCAGAUACUAUTT 3', 5'GGUAUUCCUGUUGUUGAAC 3 'and 5' AGCCCGAUCCUUUCUUCAUUU 3'.

\section{Western blot}

Whole-cell lysates were used for immunoblotting as described previously [67].

\section{Measurement of mitochondrial membrane potential}

5,5',6,6'-tetrachloro-1,1',3,3'-tetraethylbenzimidazolocar bocyanine iodide (JC-1) dye (sigma) exhibits potential-dependent accumulation in the mitochondria, and JC-1 selectively enters the mitochondria and spontaneously forms complexes known as J-aggregates. If the membrane potential is disturbed, the dye remains in the monomeric form, emitting only green fluorescence. Thus, this dye was employed to detect changes in the mitochondrial membrane potential $(\Delta \Psi \mathrm{m})$. JC-1 dye was added to the culture medium at $10 \mu \mathrm{g} / \mathrm{ml}$ and incubated for $15 \mathrm{~min}$ at $37^{\circ} \mathrm{C}$. After mounting on the slides, the cells were immediately examined under a fluorescence microscope (Olympus).

\section{In vivo antitumor activity}

The in vivo efficacy of A35 was evaluated with HepG2 xenografts in nude mouse (purchased from Experimental Animals, Chinese Academy of Medical Sciences \& Peking Union Medical College). First, $1 \times 10^{7}$ HepG 2 cells suspended in $200 \mu \mathrm{l}$ of PBS were inoculated s.c. in the right armpits of nude mice. After 3 weeks, the tumors were removed from the nude mice and dissected aseptically in sterile saline. Pieces of tumor tissue $\left(2 \mathrm{~mm}^{3}\right.$ in size) were then transplanted into the right armpits of nude mice with a trocar. Tumor-bearing mice were randomly divided into 3 groups $(n=5)$ when the tumor size was about $100 \mathrm{~mm}^{3}$. A35 (10 or $20 \mathrm{mg} / \mathrm{kg}$ ) was administered by intraperitoneal injection once a day until the mice were sacrificed. Tumor size was measured every 3 days, and tumor volume was determined as length $\times$ width $^{2} / 2$. Mice were killed when the tumor volumes of the control group reached $1000 \mathrm{~mm}^{3}$; the tumor loads and hearts were isolated and used in further assays. 


\section{H \& E staining, detection of apoptosis and immunofluorescence of tissue sections}

Hearts from A35-administered mice were excised and preserved in liquid nitrogen until frozen heart sections were produced. In the cardiotoxicity positive control group, DOX was administered by intraperitoneal injection at $0.5 \mathrm{mg} / \mathrm{kg}$ once every two days. H\&E staining was performed as described in [68]. Slides were incubated with $0.5 \%$ Triton for $20 \mathrm{~min}$ and blocked with FBS at $37^{\circ} \mathrm{C}$ for $30 \mathrm{~min}$, and then $\gamma-\mathrm{H} 2 \mathrm{AX}$ antibody conjugated fluorescein isothiocyanate (FITC) (BD) was added overnight at $4^{\circ} \mathrm{C}$, followed by the addition of TUNEL reaction buffer (Roche Applied Science) for $10 \mathrm{~min}$. The nuclei were stained with DAPI (Sigma) before the slides were sealed and examined with a fluorescence microscope (Olympus). The $\gamma$-H2AXpositive cells and cells with apoptotic nuclei were counted at $400 \times$ magnification to obtain the total nuclei per section. Five sections from each mouse were counted and averaged.

\section{ACKNOWLEDGMENTS AND GRANT SUPPORT}

The authors thank Jason T. Bau and Ebba U. Kurz (Institute for Cellular and Molecular Biosciences, Newcastle University (C.A.A)) for their sound advice regarding topoisomerase-related assays.

This work was supported by the National Science Fund (81102464 and 81321004), National Mega-project for Innovative Drugs (2014ZX09201042) and the IMB fund.

\section{CONFLICTS OF INTEREST}

No potential conflicts of interest were disclosed.

\section{REFERENCES}

1. Liu LF, Wang JC. Supercoiling of the DNA template during transcription. Proceedings of the National Academy of Sciences of the United States of America. 1987; 84:7024-7027.

2. Woessner RD, Mattern MR, Mirabelli CK, Johnson RK, Drake FH. Proliferation- and cell cycle-dependent differences in expression of the 170 kilodalton and 180 kilodalton forms of topoisomerase II in NIH-3T3 cells. Cell Growth Differ. 1991; 2:209-214.

3. Adachi N, Nomoto M, Kohno K, Koyama H. Cell-cycle regulation of the DNA topoisomerase IIalpha promoter is mediated by proximal CCAAT boxes: possible involvement of acetylation. Gene. 2000; 245:49-57.

4. Padget K, Pearson AD, Austin CA. Quantitation of DNA topoisomerase IIalpha and beta in human leukaemia cells by immunoblotting. Leukemia. 2000; 14:1997-2005.
5. Zhang S, Liu X, Bawa-Khalfe T, Lu LS, Lyu YL, Liu LF, Yeh ET. Identification of the molecular basis of doxorubicin-induced cardiotoxicity. Nat Med. 2012; 18:1639-1642.

6. Ben-David U, Cowell IG, Austin CA, Benvenisty N. Controlling the survival of human pluripotent stem cells by small molecule-based targeting of topoisomerase II alpha. Stem Cells. 2015; 33:1013-9.

7. Chen T, Sun Y, Ji P, Kopetz S, Zhang W. Topoisomerase IIalpha in chromosome instability and personalized cancer therapy. Oncogene. 2015; 34:4019-31.

8. Lodish H, Berk A, Zipursky SL, Matsudaira P, Baltimore D, Darnell J. The Role of Topoisomerases in DNA Replication. 2000.

9. Burgess DJ, Doles J, Zender L, Xue W, Ma B, McCombie WR, Hannon GJ, Lowe SW, Hemann MT. Topoisomerase levels determine chemotherapy response in vitro and in vivo. Proceedings of the National Academy of Sciences of the United States of America. 2008; 105:9053-9058.

10. Nitiss JL. Targeting DNA topoisomerase II in cancer chemotherapy. Nat Rev Cancer. 2009; 9:338-350.

11. Dowlati A, Levitan N, Gordon NH, Hoppel CL, Gosky DM, Remick SC, Ingalls ST, Berger SJ, Berger NA. Phase II and pharmacokinetic/pharmacodynamic trial of sequential topoisomerase I and II inhibition with topotecan and etoposide in advanced non-small-cell lung cancer. Cancer Chemother Pharmacol. 2001; 47:141-148.

12. Miller AA, Al Omari A, Murry DJ, Case D. Phase I and pharmacologic study of sequential topotecan-carboplatinetoposide in patients with extensive stage small cell lung cancer. Lung Cancer. 2006; 54:379-385.

13. Salerno S, Da Settimo F, Taliani S, Simorini F, La Motta C, Fornaciari G, Marini AM. Recent advances in the development of dual topoisomerase I and II inhibitors as anticancer drugs. Curr Med Chem. 2010; 17:4270-4290.

14. Vejpongsa P, Yeh ET. Topoisomerase 2beta: a promising molecular target for primary prevention of anthracyclineinduced cardiotoxicity. Clin Pharmacol Ther. 2014; 95:45-52.

15. Janockova J, Plsikova J, Koval J, Jendzelovsky R, Mikes J, Kasparkova J, Brabec V, Hamulakova S, Fedorocko P, Kozurkova M. Tacrine derivatives as dual topoisomerase I and II catalytic inhibitors. Bioorg Chem. 2015; 59:168-176.

16. Jobson AG, Willmore E, Tilby MJ, Mistry P, Charlton P, Austin CA. Effect of phenazine compounds XR11576 and XR5944 on DNA topoisomerases. Cancer Chemother Pharmacol. 2009; 63:889-901.

17. Rao VA, Agama K, Holbeck S, Pommier Y. Batracylin (NSC 320846), a dual inhibitor of DNA topoisomerases I and II induces histone gamma-H2AX as a biomarker of DNA damage. Cancer Res. 2007; 67:9971-9979.

18. Yao BL, Mai YW, Chen SB, Xie HT, Yao PF, Ou TM, Tan JH, Wang HG, Li D, Huang SL, Gu LQ, Huang ZS. Design, synthesis and biological evaluation of novel 
7-alkylamino substituted benzo[a]phenazin derivatives as dual topoisomerase I/II inhibitors. Eur J Med Chem. 2015; 92:540-553.

19. Du K, Liang J, Wang Y, Kou J, Qian C, Ji L, Chao H. Dual inhibition of topoisomerases I and IIalpha by ruthenium(ii) complexes containing asymmetric tridentate ligands. Dalton Trans. 2014; 43:17303-17316.

20. Bau JT, Kang Z, Austin CA, Kurz EU. Salicylate, a Catalytic Inhibitor of Topoisomerase, II, Inhibits DNA Cleavage and Is Selective for the $\alpha$ Isoform. Molecular pharmacology. 2014; 85:198-207.

21. Hisatomi T, Sueoka-Aragane N, Sato A, Tomimasu R, Ide M, Kurimasa A, Okamoto K, Kimura S, Sueoka E. NK314 potentiates antitumor activity with adult T-cell leukemia-lymphoma cells by inhibition of dual targets on topoisomerase II $\{$ alpha $\}$ and DNA-dependent protein kinase. Blood. 2011; 117:3575-3584.

22. Onda T, Toyoda E, Miyazaki O, Seno C, Kagaya S, Okamoto K, Nishikawa K. NK314, a novel topoisomerase II inhibitor, induces rapid DNA double-strand breaks and exhibits superior antitumor effects against tumors resistant to other topoisomerase II inhibitors. Cancer Lett. 2008; 259:99-110.

23. Toyoda E, Kagaya S, Cowell IG, Kurosawa A, Kamoshita K, Nishikawa K, Iiizumi S, Koyama H, Austin CA, Adachi N. NK314, a topoisomerase II inhibitor that specifically targets the alpha isoform. J Biol Chem. 2008; 283:23711-23720.

24. Kuo CL, Chi CW, Liu TY. The anti-inflammatory potential of berberine in vitro and in vivo. Cancer Lett. 2004; 203:127-137.

25. Hwang JM, Wang CJ, Chou FP, Tseng TH, Hsieh YS, Lin WL, Chu CY. Inhibitory effect of berberine on tert-butyl hydroperoxide-induced oxidative damage in rat liver. Arch Toxicol. 2002; 76:664-670.

26. Mantena SK, Sharma SD, Katiyar SK. Berberine, a natural product, induces G1-phase cell cycle arrest and caspase3 -dependent apoptosis in human prostate carcinoma cells. Mol Cancer Ther. 2006; 5:296-308.

27. Lin JP, Yang JS, Lee JH, Hsieh WT, Chung JG. Berberine induces cell cycle arrest and apoptosis in human gastric carcinoma SNU-5 cell line. World J Gastroenterol. 2006; 12:21-28.

28. Nitiss JL, Wang JC. Mechanisms of cell killing by drugs that trap covalent complexes between DNA topoisomerases and DNA. Mol Pharmacol. 1996; 50:1095-1102.

29. Tomicic MT, Christmann M, Kaina B. Topotecan triggers apoptosis in $\mathrm{p} 53$-deficient cells by forcing degradation of XIAP and survivin thereby activating caspase3-mediated Bid cleavage. J Pharmacol Exp Ther. 2010; 332:316-325.

30. Fan JY, Valu KK, Woodgate PD, Baguley BC, Denny WA. Aniline mustard analogues of the DNA-intercalating agent amsacrine: DNA interaction and biological activity. Anticancer Drug Des. 1997; 12:181-203.
31. Takagi T, Naito Y, Okada H, Ishii T, Mizushima K, Akagiri S, Adachi S, Handa O, Kokura S, Ichikawa H, Itoh K, Yamamoto M, Matsui H, Yoshikawa T. Lansoprazole, a proton pump inhibitor, mediates anti-inflammatory effect in gastric mucosal cells through the induction of heme oxygenase-1 via activation of NF-E2-related factor 2 and oxidation of kelch-like ECH-associating protein 1. J Pharmacol Exp Ther. 2009; 331:255-264.

32. Jing D, Beechem JM, Patton WF. The utility of a twocolor fluorescence electrophoretic mobility shift assay procedure for the analysis of DNA replication complexes. Electrophoresis. 2004; 25:2439-2446.

33. Stokes NR, Thomaides-Brears HB, Barker S, Bennett JM, Berry J, Collins I, Czaplewski LG, Gamble V, Lancett P, Logan A, Lunniss CJ, Peasley H, Pommier S, Price D, Smee C, Haydon DJ. Biological evaluation of benzothiazole ethyl urea inhibitors of bacterial type II topoisomerases. Antimicrob Agents Chemother. 2013; 57:5977-5986.

34. Robinson MJ, Osheroff N. Effects of antineoplastic drugs on the post-strand-passage DNA cleavage/religation equilibrium of topoisomerase II. Biochemistry. 1991; 30:1807-1813.

35. Huelsenbeck SC, Schorr A, Roos WP, Huelsenbeck J, Henninger C, Kaina B, Fritz G. Rac1 protein signaling is required for DNA damage response stimulated by topoisomerase II poisons. J Biol Chem. 2012; 287:38590-38599.

36. Chamberlain GR, Tulumello DV, Kelley SO. Targeted delivery of doxorubicin to mitochondria. ACS Chem Biol. 2013; 8:1389-1395.

37. Shizukuda Y, Matoba S, Mian OY, Nguyen T, Hwang PM. Targeted disruption of p53 attenuates doxorubicininduced cardiac toxicity in mice. Mol Cell Biochem. 2005; 273:25-32.

38. Janovec L, Kozurkova M, Sabolova D, Ungvarsky J, Paulikova H, Plsikova J, Vantova Z, Imrich J. Cytotoxic 3,6-bis((imidazolidinone)imino)acridines: synthesis, DNA binding and molecular modeling. Bioorg Med Chem. 2011; 19:1790-1801.

39. Gao C, Liu F, Luan X, Tan C, Liu H, Xie Y, Jin Y, Jiang Y. Novel synthetic 2-amino-10-(3,5-dimethoxy) benzyl-9(10H)-acridinone derivatives as potent DNAbinding antiproliferative agents. Bioorg Med Chem. 2010; 18:7507-7514.

40. Lafayette EA, Vitalino de Almeida SM, Pitta MG, Carneiro Beltrao EI, da Silva TG, Olimpio de Moura R, Pitta Ida R, de Carvalho LB Jr., de Lima Mdo C. Synthesis, DNA binding and topoisomerase I inhibition activity of thiazacridine and imidazacridine derivatives. Molecules. 2013; 18:15035-15050.

41. Denny WA. Dual topoisomerase I/II poisons as anticancer drugs. Expert Opin Investig Drugs. 1997; 6:1845-1851.

42. Li Z, Sun B, Clewell RA, Adeleye Y, Andersen ME, Zhang Q. Dose-response modeling of etoposide-induced DNA damage response. Toxicol Sci. 2014; 137:371-384. 
43. Schmidt BH, Osheroff N, Berger JM. Structure of a topoisomerase II-DNA-nucleotide complex reveals a new control mechanism for ATPase activity. Nature structural \& molecular biology. 2012; 19:1147-1154.

44. Pommier Y, Leo E, Zhang H, Marchand C. DNA topoisomerases and their poisoning by anticancer and antibacterial drugs. Chem Biol. 2010; 17:421-433.

45. Fortune JM, Osheroff N. Topoisomerase II as a target for anticancer drugs: when enzymes stop being nice. Progress in nucleic acid research and molecular biology. 2000; 64:221-253.

46. Qin Y, Pang JY, Chen WH, Zhao ZZ, Liu L, Jiang ZH. Inhibition of DNA topoisomerase I by natural and synthetic mono- and dimeric protoberberine alkaloids. Chem Biodivers. 2007; 4:481-487.

47. Makhey D, Gatto B, Yu C, Liu A, Liu LF, LaVoie EJ. Coralyne and related compounds as mammalian topoisomerase I and topoisomerase II poisons. Bioorg Med Chem. 1996; 4:781-791

48. Wang LK, Rogers BD, Hecht SM. Inhibition of topoisomerase I function by coralyne and 5,6-dihydrocoralyne. Chem Res Toxicol. 1996; 9:75-83.

49. Jantova S, Cipak L, Letasiova S. Berberine induces apoptosis through a mitochondrial/caspase pathway in human promonocytic U937 cells. Toxicol In Vitro. 2007; 21:25-31.

50. Choi MS, Yuk DY, Oh JH, Jung HY, Han SB, Moon DC, Hong JT. Berberine inhibits human neuroblastoma cell growth through induction of p53-dependent apoptosis. Anticancer Res. 2008; 28:3777-3784.

51. Eom KS, Hong JM, Youn MJ, So HS, Park R, Kim JM, Kim TY. Berberine induces G1 arrest and apoptosis in human glioblastoma T98G cells through mitochondrial/ caspases pathway. Biol Pharm Bull. 2008; 31:558-562.

52. Kulbacka J , Chwilkowska A, Choromańska A, Saczko J, Skołucka N. Apoptosis, free radicals and antioxidant defense in antitumor therapy. INTECH Open Access Publisher. 2012.

53. Austin CA, Marsh KL. Eukaryotic DNA topoisomerase II beta. Bioessays. 1998; 20:215-226.

54. Lyu YL, Kerrigan JE, Lin CP, Azarova AM, Tsai YC, Ban Y, Liu LF. Topoisomerase IIbeta mediated DNA double-strand breaks: implications in doxorubicin cardiotoxicity and prevention by dexrazoxane. Cancer Res. 2007; 67:8839-8846.

55. Azarova AM, Lyu YL, Lin CP, Tsai YC, Lau JY, Wang JC, Liu LF. Roles of DNA topoisomerase II isozymes in chemotherapy and secondary malignancies. Proceedings of the National Academy of Sciences of the United States of America. 2007; 104:11014-11019.
56. Meng LH, Zhang JS, Ding J. Salvicine, a novel DNA topoisomerase II inhibitor, exerting its effects by trapping enzyme-DNA cleavage complexes. Biochem Pharmacol. $2001 ; 62: 733-741$.

57. Sooryakumar D, Dexheimer TS, Teicher BA, Pommier Y. Molecular and cellular pharmacology of the novel noncamptothecin topoisomerase I inhibitor Genz-644282. Mol Cancer Ther. 2011; 10:1490-1499.

58. Dexheimer TS, Pommier Y. DNA cleavage assay for the identification of topoisomerase I inhibitors. Nat Protoc. 2008; 3:1736-1750.

59. Beck DE, Abdelmalak M, Lv W, Reddy PV, Tender GS, O'Neill E, Agama K, Marchand C, Pommier Y, Cushman M. Discovery of potent indenoisoquinoline topoisomerase I poisons lacking the 3-nitro toxicophore. J Med Chem. 2015; 58:3997-4015.

60. Lin Z, Wang TY, Tsai BS, Wu FT, Yu FJ, Tseng YJ, Sung HM, Li WH. Identifying cis-regulatory changes involved in the evolution of aerobic fermentation in yeasts. Genome biology and evolution. 2013; 5:1065-1078.

61. Kingma PS, Fortune JM, Osheroff N. Topoisomerase II-catalyzed ATP hydrolysis as monitored by thin-layer chromatography. Methods Mol Biol. 2001; 95:51-56.

62. Austin CA, Marsh KL, Wasserman RA, Willmore E, Sayer PJ, Wang JC, Fisher LM. Expression, domain structure, and enzymatic properties of an active recombinant human DNA topoisomerase II beta. J Biol Chem. 1995; 270:15739-15746.

63. Stros M, Bacikova A, Polanska E, Stokrova J, Strauss F. HMGB1 interacts with human topoisomerase IIalpha and stimulates its catalytic activity. Nucleic Acids Res. 2007; 35:5001-5013.

64. Znojek P, Willmore E, Curtin NJ. Preferential potentiation of topoisomerase I poison cytotoxicity by PARP inhibition in S phase. Br J Cancer. 2014; 111:1319-1326.

65. Rojas E, Lopez MC, Valverde M. Single cell gel electrophoresis assay: methodology and applications. J Chromatogr B Biomed Sci Appl. 1999; 722:225-254.

66. Zhao W, He H, Ren K, Li B, Zhang H, Lin Y, Shao RG. MR-1 blocks the megakaryocytic differentiation and transition of CML from chronic phase to blast crisis through MEK dephosphorylation. Blood Cancer J. 2013; 3:e107.

67. Zhao W, He H, Ren K, Zhang H, Chen Y, Shao R. Myofibrillogenesis regulator-1 promotes cell adhesion and migration in human hepatoma cells. Chinese Science Bulletin. 2013; 58:3007-3014.

68. Fischer AH, Jacobson KA, Rose J, Zeller R. Hematoxylin and eosin staining of tissue and cell sections. CSH Protoc. 2008; 2008:pdb prot4986. 